\title{
1 Crustal Recycling by Subduction Erosion in the central Mexican Volcanic Belt
}

4 Susanne M. Straub¹,2, Arturo Gómez-Tuena ${ }^{3}$, Ilya N. Bindeman', Louise L. Bolge, Philipp A.

5 Brandl ${ }^{5}$, Ramón Espinasa-Perena ${ }^{6}$, Luigi Solari ${ }^{3}$, Finlay M. Stuart 7 , Paola Vannucchi ${ }^{8}$ and Georg F.

Zellmer $^{9}$

9 'Lamont Doherty Earth Observatory at the Columbia University, 61 Route 9W, Palisades NY 10964,

10 U.S.A.

11 'Institute of Earth Sciences, Academia Sinica, 128 Academia Road, Sec. 2, Nankang, Taipei 11529,

12 Taiwan, $R O C$

$13{ }^{3}$ Centro de Geociencias, Universidad Nacional Autónoma de México, Querétaro 76230, México

$14{ }^{4}$ Department of Geological Sciences, University of Oregon, Eugene, Oregon, 97403-1272, U.S.A.

$15{ }^{5}$ Research School of Earth Sciences, Mills Road, The Australian National University, Canberra ACT 0200,

16 Australia

$17{ }^{6}$ Centro Nacional de Prevención de Desastres, Secretaría de Gobernación, Av. Delfín Madrigal 665, Col.

18 Pedregal de Santo Domingo C.P.04360, Delegación Coyoacán, México D.F

19 'Isotope Geosciences Unit, Scottish Universities Research and Reactor Centre, East Kilbride G75 0QF, UK

$20{ }^{8}$ Department of Earth Sciences, Royal Holloway, University of London Egham, Surrey, TW20 0EX, UK

21 Institute of Agriculture and Environment, Massey University, Palmerston North 4442, New Zealand

e-mail: smstraub@ldeo.columbia.edu

Phone: +8453658464 


\section{Abstract}

36 Recycling of upper plate crust in subduction zones, or 'subduction erosion', is a major

37 mechanism of crustal destruction at convergent margins. However, assessing the impact

38 of eroded crust on arc magmas is difficult owing to the compositional similarity between

39 the eroded crust, trench sediment and arc crustal basement that may all contribute to arc

40 magma formation. Here we compare $\mathrm{Sr}-\mathrm{Nd}-\mathrm{Pb}-\mathrm{Hf}$ and trace element data of crustal

41 input material to $\mathrm{Sr}-\mathrm{Nd}-\mathrm{Pb}-\mathrm{Hf}-\mathrm{He}-\mathrm{O}$ isotope chemistry of a well-characterized series of

42 olivine-phyric, high-Mg\# basalts to dacites in the central Mexican Volcanic Belt (MVB).

43 Basaltic to andesitic magmas crystallize high-Ni olivines that have high mantle-like

$44{ }^{3} \mathrm{He} /{ }^{4} \mathrm{He}=7-8 \mathrm{R}$ and high crustal $\delta^{18} \mathrm{O}_{\text {melt }}=+6.3-8.5 \%$ implying their host magmas to be

45 near-primary melts from a mantle infiltrated by slab-derived crustal components.

46 Remarkably, their Hf-Nd isotope and $\mathrm{Nd} / \mathrm{Hf}$ trace element systematics rule out the

47 trench sediment as the recycled crust end member, and imply that the coastal and

48 offshore granodiorites are the dominant recycled crust component. Sr-Nd-Pb-Hf isotope

49 modeling shows that the granodiorites control the highly to moderately incompatible

50 elements in the calc-alkaline arc magmas, together with lesser additions of $\mathrm{Pb}$ - and $\mathrm{Sr}-$

51 rich fluids from subducted mid-oceanic ridge basalt (MORB)-type altered oceanic crust

52 (AOC). Nd-Hf mass balance suggests that the granodiorite exceeds the flux of the trench

53 sediment by at least 9-10 times, corresponding to a flux of $\geq 79-88 \mathrm{~km}^{3} / \mathrm{km} / \mathrm{Myr}$ into the

54 subduction zone. At an estimated thickness of $1500-1700 \mathrm{~m}$, the granodiorite may

55 buoyantly rise as bulk 'slab diapirs' into the mantle melt region and impose its trace

56 element signature (e.g. $\mathrm{Th} / \mathrm{La}, \mathrm{Nb} / \mathrm{Ta}$ ) on the prevalent calc-alkaline arc magmas. Deep

57 slab melting and local recycling of other slab components such as oceanic seamounts

58 further diversify the MVB magmas by producing rare, strongly fractionated high-La

59 magmas and a minor population of high-Nb magmas, respectively. Overall, the central

60 MVB magmas inherit their striking geochemical diversity principally from the slab, thus

61 emphasizing the importance of continental crust recycling in modern solid Earth relative

62 to its new formation in modern subduction zones.

\section{1. INTRODUCTION}

64 Subduction zone magmas share remarkable compositional similarities with the

65 continental crust. This has triggered a longstanding and controversial debate regarding

66 whether the continental crust was extracted from the Earth's mantle by processes similar

67 to those of modern convergent margins (e.g. Harrison, 2009; Plank, 2004; Stern, 2011;

68 Taylor, 1967). A pivotal question in this debate is the extent to which subduction 
69 processing can create the typical fractionated trace element signature of the continental

70 crust, or whether this signature is mostly inherited through perpetual recycling of

71 continental crust in subduction zones (e.g. Plank, 2004; Rudnick, 1995). Continental crust

72 is recycled in subduction zones by means of the oceanic sediment subducted at the

73 trenches ('trench sediment') and by subduction erosion of the upper plate crust (Clift

74 and Vannucchi, 2004; Huene and Scholl, 1991). Trench sediment accumulates by surface

75 erosion of the continental crust and resembles average upper continental crust (Plank,

76 2004; Plank and Langmuir, 1993). Eroded crust is continental crust that is mechanically

77 removed by the subducting slab from forearc basement either by frontal or basal tectonic

78 erosion (Huene et al., 2004; Huene and Scholl, 1991).

79 Trench sediment recycling has been deduced by the strong compositional links

80 between arc magmas and conjugate trench sediments (e.g. Kay, 1980; Kelemen et al.,

81 2003; Morris et al., 2002; Morris et al., 1990; Plank, 2004; Plank and Langmuir, 1993), and

82 unequivocally confirmed by the detection of cosmogenic ${ }^{10} \mathrm{Be}$ in young arc lavas (Morris

83 et al., 2002; Tera et al., 1986). In contrast, subduction erosion was first recognized from

84 geological observations. For example, uplifted igneous plutonic roots of older arcs may

85 be exposed trenchward to modern arcs which suggests a landward retreat of the trench

86 and forearc crustal removal (Huene and Scholl, 1991; Schaaf et al., 1995). Missing crust is

87 also indicated by vertical fore-arc subsidence without horizontal extension or depression

88 (Huene and Scholl, 1991; Ranero and Huene, 2000). The intensity of subduction erosion

89 may vary considerably through time and among different arc-trench systems (Clift and

90 Vannucchi, 2004; Stern, 2011). On a global scale, mass balance calculations show that

91 subduction erosion accounts for about half ( 44-50\%) of the crust recycled in subduction

92 zones relative to the trench sediment ( 42-56\%) (Clift et al., 2009; Scholl and Huene,

93 2009). Regionally, eroded crust may even exceed the mass of trench sediment by up to a

94 factor of 10 (Vannucchi et al., 2003). Clearly, in view of these numbers, the recycled

95 eroded crust must leave a chemical imprint on the arc that rivals the influence of the

96 recycled trench sediment.

97 Confirming the recycling of eroded crust in the compositions of arc magmas,

98 however, is a major challenge. The eroded crust mingles with the incoming trench

99 sediment and subducted igneous oceanic basement (AOC, altered oceanic crust), and re-

100 emerges in volcanic arcs together with material from the mantle, and possibly

101 contaminated by the arc's crustal basement. These components must then be

102 distinguished from each other in arc magmas, whereby the eroded crust is similar to

103 trench sediment and arc basement. No unique tracer exists, such as ${ }^{10}$ Be for oceanic 
104 trench sediment. To add complexity, basal crust from the underside of the upper plate is

105 not accessible, which forestalls direct comparison to arc compositions. Nevertheless,

106 from comprehensive $\mathrm{Sr}-\mathrm{Nd}-\mathrm{Pb}-\mathrm{B}$ isotope and trace element studies of arc magmas,

107 evidence for the presence of fore-arc eroded crust has begun to accumulate (e.g. Goss

108 and Kay, 2006; Goss et al., 2013; Holm et al., 2014; Kay et al., 2005; Risse et al., 2013;

109 Tonarini et al., 2011). The common factor of these studies is that they integrate geological

110 and geochemical observations that allow the detection of compositional mismatch

111 between arc chemistry and trench input from the subducted slab that may be reconciled

112 by crust removed from the fore-arc regions.

113 In the global spectrum of arc magmas, the Mexican margin is a prime setting for

114 tracing the eroded crust in volcanic arcs. First, there is strong evidence for long-term

115 crustal erosion along the Mexican Trench indicated by trench retreat and fore-arc uplift

116 (Clift and Vannucchi, 2004), and by large volumes of missing Mesozoic and Cenozoic

117 crust along the coast (Ducea et al., 2004; Keppie et al., 2012; Morán-Zenteno et al., 1996;

118 Schaaf et al., 1995). Second, the subducted crustal materials - trench sediment, AOC,

119 eroded crust - are obtainable from drill sites at the trench and offshore continental slope

120 as well as from coastal outcrops (exposed Acapulco intrusion, Hernández-Pineda et al.,

121 2011; Watkins and Moore, 1981). Since these crustal materials have distinct

122 compositions, they should be traceable in the arc magmas. Here we report the results of

123 comprehensive comparison between $\mathrm{Sr}-\mathrm{Nd}-\mathrm{Pb}-\mathrm{Hf}-\mathrm{O}-\mathrm{He}$ isotope and trace element data

124 of olivine-bearing arc magmas from the central Mexican Volcanic Belt (MVB) and Sr-Nd-

$125 \mathrm{~Pb}-\mathrm{Hf}$ isotope and trace elements of relevant crustal input materials from the subducting

126 and overlying slab. Our data imply that crust recycled by subduction erosion controls

127 much of the chemistry of the arc magmas erupted in the central MVB.

\section{2. GEOLOGICAL SETTING}

129 The Mexican Volcanic Belt is an active Pliocene-Quaternary volcanic arc that is related

130 to the subduction of the Cocos and Rivera plates along the Middle American Trench

131 (Figure 1) (e.g. Gómez-Tuena et al., 2007b). The trench runs oblique to the arc volcanic

132 front at an angle of $\sim 17^{\circ}$, because the slab dip decreases eastward and the arc-trench gap

133 widens. In the central MVB, the slab subducts horizontally beneath the forearc and the

134 arc-trench gap measures $\sim 360$ km (Pardo and Suarez, 1995; Perez-Campos et al., 2008).

135 The study area in central Mexico comprises the monogenetic Sierra Chichinautzin

136 Volcanic Field that is flanked by the composite volcanoes Nevado de Toluca (west) and

137 Popocatepetl (east) (Figure 1, 2). The volcanoes are constructed on a $\sim 45 \mathrm{~km}$ thick sialic

138 crust of Proterozoic granulites and Mesozoic metapelites, granites and limestones (e.g. 
139 Ortega-Gutiérrez et al., 2012). An extensional crustal stress regime facilitates magma

140 ascent, and mafic and high-Mg\# olivine-phyric basalts and andesites are common

141 (Gómez-Tuena et al., 2007b; Schaaf et al., 2005; Wallace and Carmichael, 1999).

142 Magma compositions in the central MVB range from basalt to dacites which display

143 considerable diversity in trace elements (e.g. Cai et al., 2014; LaGatta, 2003, and

144 references therein; Martinez-Serrano et al., 2004; Schaaf et al., 2005; Siebe et al., 2004a;

145 Straub et al., 2013a; Straub et al., 2014; Wallace and Carmichael, 1999). For petrogenetic

146 studies it was useful to distinguish between a 'basaltic' (olivine-normative) and

147 'andesitic' (quartz-normative) group, respectively (e.g. Straub et al., 2011b; 2013a; 2014).

148 For the discussion of recycling processes, however, we prefer a division based on the

149 source-sensitive incompatible trace elements (Figure 3). In trace element space, three

150 groups with basaltic and andesitic compositions can be distinguished (see also

151 Appendix A, Figure 1a). The first and far most abundant group (estimated $>95$ vol\% of

152 erupted magmas) are calk-alkaline basalts to dacites (50-67 wt \% SiO 2$)$ which construct

153 the voluminous (several $100 \mathrm{~km}^{3}$ ) composite volcanoes and most of the small-volume $(\leq 1$

$154 \mathrm{~km}^{3}$ ) monogenetic cones. Calc-alkaline magmas combine low $\mathrm{Nb}=4-14 \mathrm{ppm}$

155 abundances with arc-typical strong enrichments of large-ion lithophile elements (LILE)

156 relative to the rare earth elements (REE) and high-field-strength elements (HFSE). The

157 second group ('high-La') consists of light REE (LREE)-enriched basalts to basaltic

158 andesites that have strongly fractionated trace element patterns with strong enrichments

159 in $\mathrm{K}_{2} \mathrm{O}$ and LREE, relative depletions in $\mathrm{Zr}$-Hf and steep heavy REE (HREE) patterns.

160 'High-La' magmas were first described by Gomez-Tuena et al. (2007a) in the Valle de

161 Bravo west of Nevado de Toluca. In the central MVB, only a few high-La magmas erupt

162 from small, monogenetic volcanoes but these magmas are more common in western

163 Mexico (Gomez-Tuena et al., 2011). The third group consists of Nb-rich (>17-36 ppm),

164 mildly alkaline basalts to basaltic andesites (49-57 $\left.\mathrm{wt} \% \mathrm{SiO}_{2}\right)$. Nb-rich magmas are

165 enriched in LILE, REE and HFSE, and their trace element pattern resemble those of

166 enriched intraplate basalts (LaGatta, 2003; Schaaf et al., 2005; Straub et al., 2013a; Wallace

167 and Carmichael, 1999). Nb-rich magmas are ubiquitous in the rear-arc region of the

168 MVB, but are rare along the arc volcanic front (e.g. Díaz-Bravo et al., 2014; Gómez-Tuena

169 et al., 2007b; Luhr, 1997).

170 In the central MVB, Nb-rich magmas erupt from a small, likely coeval group (ca. 1600-

1711800 year ago, Siebe, 2000; Siebe et al., 2004b; Straub et al., 2013b) of monogenetic

172 volcanoes in the center of the Sierra Chichinautzin, located halfway between

173 Popocatepetl and Nevada de Toluca (Figure 2) (e.g. Straub et al., 2013b; Wallace and 
174 Carmichael, 1999). These Nb-rich magmas are closely associated with the calc-alkaline

175 magmas, erupting from vents only a few kilometers and a few thousands year apart,

176 and even from the same volcano (e.g. Suchiooc, Schaaf et al., 2005; Siebe et al., 2004a;

177 Straub et al., 2013a; Straub et al., 2014). In our sample set, the Nb-rich magmas are over-

178 represented, because they were the target of a more detailed study (Straub et al., 2013a,

179 2013b).

180 3. ARC MAGMA PETROGENESIS IN THE CENTRAL MVB

181 The impact of slab contributions (such as slab fluids, slab partial melts and more

182 recently 'slab diapirs', hereafter summarily referred to as 'slab components') on arc

183 magmas and its consequences for arc petrogenesis and subduction cycling are at the core

184 of arc research (e.g. Gomez-Tuena et al., 2014; Hacker et al., 2011; Plank, 2004). This

185 question is also intensely debated in the central MVB, where much recent progress was

186 made, and for which a short summary is provided here.

187 The central MVB is constructed on thick continental basement and consequently many 188 studies propose that andesites and dacites evolve from primary basaltic mantle melt by 189 crustal processing (fractional crystallization, crustal assimilation) (e.g. Agustín-Flores et 190 al., 2011; Marquez et al., 1999; Verma, 1999a). However, in recent years evidence has 191 accumulated from several comprehensive petrologic and geochemical studies that the 192 entire range of central MVB basaltic to andesitic (and even dacitic and ryolitic) magmas

193 are near-primary melts from a subduction-modified mantle that pass the crustal 194 basement nearly unchanged (Gomez-Tuena et al., 2007a; Gómez-Tuena et al., 2008;

195 Straub et al., 2011a; Straub et al., 2013a; Straub et al., 2008). In these models high-Ni

196 olivines with up to 5400 ppm Ni play a key role (Appendix A, Figures 1b,c). These

197 olivines crystallize from basaltic and andesitic magmas and have high ${ }^{3} \mathrm{He} /{ }^{4} \mathrm{He}$ ratios of

198 7-8 Ra which confirms that their host magmas originate in upper mantle. Moreover, the

199 high Ni concentrations in olivine suggests that these magmas are partial melts of

200 secondary olivine-free pyroxenite segregations in the mantle wedge (Straub et al.,

201 2011b). Such segregations formed following the infiltration of silicic components from

202 slab. They melt preferentially relative to the surrounding peridotite in an upwelling

203 mantle and produce a broader range of primary basaltic to dacitic melts that mix

204 variably during ascent to form andesites (Straub et al., 2011a; Straub et al., 2013a; Straub

205 et al., 2008). A major implication of this 'pyroxenite model' is that the central MVB

206 magmas are principally mixtures of slab and mantle materials that underwent little, or

207 negligible, processing in the shallow crust. Thus, the budget of their highly incompatible 
208 trace elements must be strongly controlled by recycled slab materials with little

209 influence of the subarc mantle.

210 This inference has to date been confirmed by follow-up studies which provided

211 additional insights (e.g. Straub et al., 2013a; 2014). First, the central MVB 'background

212 mantle' (mantle without subduction influence) is highly depleted through serial

213 ('repetitive') melting that is triggered by the continuous hydrous flux from slab since the

214 arc became active in Pliocene. Thus, the mantle wedge is very susceptible to be

215 chemically overprinted by slab additions (2013a; Straub et al., 2008; 2014). The effect of

216 only a few percent melt extraction on the pre-subduction mantle is illustrated in

217 Figure 3, by means of modeling the 'Old Texcal Flow'. This is a monogenetic basalt flow

218 that shows the least slab influence in central Mexico [e.g. lowest $\mathrm{SiO}_{2} \sim 49 \mathrm{wt} \%$, highest

$219 \mathrm{TiO}_{2} \sim 2 \mathrm{wt} \%$ and lowest $\mathrm{Ni}$ in olivines that are only slightly higher than the Ni of

220 olivines in mid-ocean ridge basalts (MORB)], and is considered as best proxy to a melt

221 from the original mantle wedge (Straub et al., 2013a). In incompatible trace elements, the

222 'Old Texcal Flow' resembles a $\sim 3-4 \%$ partial melt of the average primitive mantle (or

223 'pyrolite') as given by McDonough and Sun (1995) [see Straub (2013a)]. However, the

224 'Old Texcal Flow' has no end member character in trace element space (Figure 3). While

225 the 'Old Texcal Flow' is per definition a high-Nb basalt ( $\mathrm{Nb}>17 \mathrm{ppm})$, it has the lowest

$226 \mathrm{Nb}$ abundances of this group $(\mathrm{Nb}=17-19 \mathrm{ppm})$ and is largely intermediate to calc-

227 alkaline and high-Nb series in other incompatible trace elements (Straub et al., 2014).

228 Therefore, primitive mantle cannot be the prevalent background mantle as it would

229 produce melts that are too enriched in HFSE and light REE for the calc-alkaline series.

230 However, a residual of primitive mantle, produced after only $>3-10 \%$ melt loss, is highly

231 depleted incompatible elements, and can easily be modified by slab additions (Straub et

232 al., 2014). As discussed previously, in the central MVB, most of the incompatible trace

233 elements (including elements $\mathrm{Sr}, \mathrm{Nd}, \mathrm{Pb}$ and $\mathrm{Hf}$ which are associated with isotope

234 tracers) are either exclusively, or substantially contributed from the slab (Straub et al.,

235 2013a; 2014), excepting only Ti and HREE (Ho-Lu).

236 Second, regardless of the extent of depletion by melting, the Ti and HREE (Ho-Lu) are

237 always controlled by the mantle. In other words, calc-alkaline and high-Nb magmas

238 could contain larger amount of slab material without displaying a garnet signature.

239 Model calculations for REE that use the most recent partitioning data for fluid and/or

240 melt release from slab (Klimm et al., 2008; Skora and Blundy, 2010) show that absorption

241 of up to $30 \%$ of slab material would not increasing $\mathrm{Ho} / \mathrm{Lu}$ of the metasomatized mantle

242 above MORB levels (Straub et al., 2013a; 2014). This amount agrees well with the 
243 'pyroxenite model' that requires a minimum of 15-18\% (and likely more) of a silicic slab

244 component in the source in order to convert peridotite to olivine-free pryoxenite (2011b;

245 Straub et al., 2008).

246 In summary, there is a confluence of evidence for strong slab contributions to the 247 mantle source that may make up several tens of percent of the erupted magmas (2014;

248 Gomez-Tuena et al., 2007a; Straub et al., 2011b; 2013a; 2014). At such proportions, the

249 slab components must control the highly incompatible trace element budgets of the

250 magmas. Moreover, slab components may range from strongly fractionated varieties to

251 components that equally mobilize fluid-mobile LILE, HFSE and LREE. Such diversity -

252 that likely represents heterogeneous slab material rather than an extreme range of

253 fractionation - would be ideal to produce the trace element diversity of calc-alkaline,

254 high-La and $\mathrm{Nb}$-rich series that are so closely associated in time and space. Thus, the

255 central MVB magmas are not only suitable for more detailed investigations of the impact

256 of the slab flux on arc chemistry, but such studies are also a vital test of the prevailing

257 petrogenetic models.

\section{4. SAMPLES AND DATA FOR THIS STUDY}

259 Here we present new $\delta^{18} \mathrm{O}$ data $(n=51)$ for olivine phenocrysts, together with new Hf

260 and $\mathrm{Pb}$ isotope ratios of representative bulk rock samples ( $\mathrm{n}=37$ samples). Most of these

261 samples have previously been analyzed for major and trace element abundances, Sr and

$262 \mathrm{Nd}$ isotope ratios, and the olivines have been analyzed for composition and ${ }^{3} \mathrm{He} /{ }^{4} \mathrm{He}$

263 (2011b; 2013a; Straub et al., 2008; 2014). In addition, 22 new volcanic rock samples were

264 analyzed for major and trace elements and $\mathrm{Sr}-\mathrm{Nd}-\mathrm{Pb}-\mathrm{Hf}$ isotopes, as well as for major

265 element oxide and Ni concentrations of olivines of six samples (Appendix B Tables 1-5).

266 Furthermore, we analyzed up to 22 selected samples of crustal material (xenoliths,

267 basement) for major and trace elements and $\mathrm{Sr}-\mathrm{Nd}-\mathrm{Pb}-\mathrm{Hf}$ isotope data (Appendix B

268 Tables 6-9) in order to complement the published data of crustal rocks from the

269 continental basement and offshore central Mexico (Figure 1). All new and previously

270 published data are summarized in Appendix B Table 10.

\section{4.1. Central Mexican arc volcanic rocks}

272 Sample locations for volcanic rocks are shown in Figure 2. Calc-alkaline samples are

273 from many monogenetic volcanoes and two composite volcanoes, Popocatepetl and

274 Toluca. The three high-La basalts and basaltic andesites are from monogenetic volcanoes

275 Yecahuazac Cone, Tuxtepec and St. Cruz. The Nb-rich series are from monogenetic

276 volcanoes Suchiooc, Chichinautzin and Texcal Flow. 
278 Crustal materials used in this study include (i) continental crustal basement on which

279 the MVB is constructed, (ii) coastal and offshore crustal basement, and (iii) the

280 terrigenous and pelagic sediment and AOC of the Cocos and Pacific plates (Figure 1).

\subsubsection{Continental crustal basement}

We obtained new Hf isotope data on crustal xenoliths from Chalcatzingo and Valle de Santiago that have previously characterized for $\mathrm{Sr}-\mathrm{Nd}-\mathrm{Pb}$ isotopes and trace elements by

284 Gómez-Tuena et al. (2008, Chalcatzingo) and Ortega-Gutiérrez et al. (2014, Valle de Santiago). Additional major and trace element data and $\mathrm{Sr}-\mathrm{Nd}-\mathrm{Pb}$ isotope ratios of outcropping crust and crustal xenoliths from within and south of the Mexican Volcanic Belt were compiled from Schaaf et al. (2005, Popocatepetl), Gomez-Tuena et al. (2003; 2008, Teziutlán (Puebla) and Chalcatzingo), Martinez-Serrano et al. (2004, Toluca), Ortega-Gutiérrez et al. (2012; 2014, Puente Negro and Valle Santiago; 2011), and PérezGutiérrez et al. (2009, Xolapa terrane).

\subsubsection{Coastal and offshore continental crust}

We obtained coastal and offshore continental crust as proxies to crust recycled by crustal erosion. The coastal samples are from the Eocene Acapulco intrusion that is now exposed at the Pacific coast south of the central MVB (Hernández-Pineda et al., 2011). Offshore samples are from DSDP Leg 66 drill sites that recovered biotite gneiss (Site 489) and granodiorite (Site 493) basement southeast of Acapulco (Figure 1). We analyzed Hf isotopes of the Acapulco intrusion [all other data are from Hernández-Pineda et al. (2011)] and major and trace element abundances and $\mathrm{Sr}-\mathrm{Nd}-\mathrm{Pb}-\mathrm{Hf}$ isotope ratios of the DSDP basement samples (Appendix B Tables 7-9).

\subsubsection{Cocos and Pacific Plates}

The crustal compositions of the incoming Cocos Plate are either AOC or oceanic sediment.

\subsubsection{Pelagic and terrigenous sediment}

304 There are two types of sediment subducted at the trench: (i) the pelagic sediment that 305 accumulated on the Cocos plate, and the (ii) terrigenous (hemipelagic) sediment from 306 the North American plate which covers the continental slope, trench and the near-trench 307 region of the Cocos plate (Watkins and Moore, 1981). The terrigenous sediment reaches 308 a minimum thickness of $625 \mathrm{~m}$ on the continental slope, and is still thicker $(105 \mathrm{~m})$ than 309 the pelagic sediment $(65 \mathrm{~m})$ at the trench Site 487 on the Cocos plate (Figure 1, Watkins 310 et al., 1981). Both sediment types were analyzed for major and trace element abundances 
and Sr-Nd-Pb-Hf isotopes by Verma (1999b), LaGatta (2003) and Cai et al. (2014), mainly with samples from DSDP Site 487 on the incoming Cocos plate, supplemented by

313 samples from DSDP Site 488 at the toe of the upper plate continental slope, and from

314 piston cores near the East Pacific Rise (Figure 1). A bulk trench sediment has been

315 calculated (Cai et al., 2014; Plank, 2014).

316 While not all data were obtained at each site, the two sediment types have clear 317 commonalities and differences. Both types have similar ${ }^{143} \mathrm{Nd} /{ }^{144} \mathrm{Nd} \sim 0.5125$ and ${ }^{87} \mathrm{Sr} /{ }^{86} \mathrm{Sr}$

$318 \sim 0.7085$, but the pelagic sediment has higher ${ }^{176} \mathrm{Hf} /{ }^{177} \mathrm{Hf}(\sim 0.28294$ vs. 0.28278$)$ and $\mathrm{Nd} / \mathrm{Hf}$

319 ( $\sim 20$ vs 8 ) than the terrigenous sediment, and is less radiogenic in Pb isotopes (e.g.

$320{ }^{206} \mathrm{~Pb} /{ }^{204} \mathrm{~Pb} 18.84$ vs 18.52) (Cai et al., 2014; LaGatta, 2003). These differences allow these

321 two lithologies to be traced through the Mexican margin given the sensitivity of arcs

322 towards trench sediment (e.g. Carpentier et al., 2008; Elliott et al., 1997; Plank and

323 Langmuir, 1993).

\subsubsection{Subducting igneous oceanic crust (AOC)}

325 The subducted AOC has been characterized for trace elements and $\mathrm{Sr}-\mathrm{Nd}-\mathrm{Pb}-\mathrm{Hf}$ 326 isotopes using the Miocene basalt basement drilled at DSDP Site 487 on the incoming 327 Cocos Plate (Cai et al., 2014; Verma, 1999b). These data and additional Sr-Nd-Pb-Hf 328 isotope analyses of two Site 487 basement samples (Appendix B Table 7) show that the

329 Site 487 basement resembles depleted zero-age mid-ocean ridge basalts of the East

330 Pacific Rise (PetDB, 2011). Nevertheless, the AOC now beneath the central MVB is about

$331 \sim 5-6$ million years older than at the trench, based on the current convergence rate of 47

$332 \mathrm{~km} / \mathrm{Ma}$ and the arc-trench gap of $360 \mathrm{~km}$ (e.g. Manea and Manea, 2011). In order to

333 preclude the possibility of a significant temporal change of the AOC, we analyzed 9

334 basaltic glasses spanning 10-72 Ma from the western flank of the East Pacific Rise

335 (Pacific Plate), assuming that the crust on both flanks of the East Pacific Rise represents

336 the upwelling mantle. Sample locations are shown in Figure 1 and include DSDP Sites 337 163, 469, 470 and 472, ODP Sites 1217A, 1243B and IODP Sites 1332, 1333 and 1334. Sr-

$338 \mathrm{Nd}-\mathrm{Pb}-\mathrm{Hf}$ isotope ratios for all sites, and major element oxide abundances for three sites

339 are given in Appendix Tables 8 and 9. The trace element composition of these MORB

340 glasses are from Brandl et al. $(2011 ; 2015)$.

\section{$341 \quad 5 . \quad$ ANALYTICAL METHODS}

342 The majority of the Hf isotope ratios $(n=37)$ were obtained at the Institute for Earth 343 Sciences (IES), Academia Sinica, Taipei, Taiwan on a Nu Plasma using the chemical Hf

344 separation technique after Lee et al. (1999). Additional $\mathrm{Sr}-\mathrm{Nd}-\mathrm{Pb}-\mathrm{Hf}$ isotope ratios of 
345 MVB lavas, crustal material and MORB glasses were obtained at Lamont using chemical

346 separation procedures developed by Cai et al. (2014). All trace element data of bulk

347 rocks were obtained by solution ICP-MS methods at the Centro de Geociencias (CGEO),

348 Juriquilla/Qro., Universidad Nacional Autónoma de México, Mexico. Major element

349 oxides were obtained by solution ICP-OES at Lamont. Oxygen isotope data of olivine

350 were obtained at the University of Oregon at Eugene. Olivine major and trace element

351 analyses and major element analyses of MORB glasses were performed at the American

352 Museum of Natural History in New York/USA. Details of analytical methods are given

353 in Appendix B together with the new data (Appendix B Tables 1-9).

$354 \quad 6 . \quad$ RESULTS

\section{6.1. O isotopes of the central MVB magmas}

356 The $\delta^{18} \mathrm{O}$ of olivines range from 5.3 to $6.6 \%$, which corresponds to $\delta^{18} \mathrm{O}$ melt $=6.3=8.4 \%$ o

357 of their basaltic and andesite equilibrium melts (Figure 4) (fractionation-correction after,

358 Bindeman, 2008). The $\delta^{18}$ Ooliv extend to higher values than those reported by Johnson et

359 al. (2009) in young basalts from monogenetic volcanoes in the Michoacan-Guanajuato

360 Volcanic Field farther to the west $\left(\delta^{18} \mathrm{O}_{\text {oliv }}=5.5-6.0 \%\right.$ o $)$. Together with the olivines of

361 Kluchevskoy volcano, Kamchatka which have $\delta^{18} \mathrm{O}_{\text {oliv }}$ up to 7.6\%o (Auer et al., 2009),

362 central Mexico has the highest $\delta^{18}$ Ooliv reported in arc magmas worldwide (Martin et al.,

363 2011). Notably, the $\mathrm{Nb}$-rich magmas have similar values and ranges in $\delta^{18} \mathrm{O}_{\text {melt }}(=$

$3647.2 \pm 0.5 \%$ o, $n=16)$ as the calc-alkaline $\left(\delta^{18} \mathrm{O}_{\text {melt }}=7.4 \pm 0.5 \%, \mathrm{n}=24\right)$ and high-La series

$365\left(\delta^{18} \mathrm{O}_{\text {melt }}=6.6-7.3 \%\right.$, $\left.n=2\right)$. The olivines of the Old Texcal Flow $\left(\delta^{18} \mathrm{O}_{\text {oliv }}=5.6 \%\right.$ o $)$, which

366 best approximates the mantle prior to subduction modification, have one of the lowest

367 melt $\delta^{18} \mathrm{O}_{\text {melt }}=6.4 \%$ of the MVB. While still slightly above the range of MORB-type

368 mantle melts $\left(\delta^{18} \mathrm{O}_{\text {melt }}=5.7 \pm 0.2 \%\right.$, Bindeman, 2008), the data confirm the end member

369 character of the Old Texcal Flow (Straub et al., 2013a).

\section{$370 \quad$ 6.2. Sr-Nd-Pb-Hf isotope ratios}

371 The $\mathrm{Sr}-\mathrm{Nd}-\mathrm{Pb}-\mathrm{Hf}$ isotope ratios of our samples are within the range reported from

372 previous studies (e.g. Cai et al., 2014; Martinez-Serrano et al., 2004; Meriggi et al., 2008;

373 Schaaf et al., 2005; Siebe et al., 2004a). Our data, however, illustrate for the first time the

374 systematic differences between calc-alkaline, high-La and Nb-rich magmas in all four

375 isotope systems (Figures 5-7). In Sr-Nd isotope space, the calk-alkaline and high-La

376 magmas are displaced to higher ${ }^{87} \mathrm{Sr} /{ }^{86} \mathrm{Sr}$ and/or higher ${ }^{143} \mathrm{Nd} /{ }^{144} \mathrm{Nd}$ relative to the $\mathrm{Nb}$ -

377 rich series (Figure 5). The Old Texcal Flow has the most radiogenic ${ }^{143} \mathrm{Nd} /{ }^{144} \mathrm{Nd}$ and least

378 radiogenic ${ }^{87} \mathrm{Sr} /{ }^{86} \mathrm{Sr}$ closest to Cenozoic MORB which agrees with its end member 
character in trace element space (Straub et al., 2013a). In Nd-Hf isotope space, the calcalkaline and high-La series, and the Nb-rich magmas, respectively, define two parallel, partially overlapping trends along the terrestrial array (Vervoort et al., 2011) (Figure 6) with the calc-alkaline series being displaced towards higher ${ }^{176} \mathrm{Hf} / 177 \mathrm{Hf}$ at a given ${ }^{143} \mathrm{Nd} /{ }^{144} \mathrm{Nd}$. Again, the Old Texcal Flow has the most radiogenic ${ }^{143} \mathrm{Nd} /{ }^{144} \mathrm{Nd}$ and ${ }^{176} \mathrm{Hf} /{ }^{177} \mathrm{Hf}$ of the central MVB magmas, close in composition to Cenozoic MORB. In $\mathrm{Pb}$ isotope space, all arc samples plot on a tight, linear array whereby the $\mathrm{Nb}$-rich series show a displacement towards more radiogenic $\mathrm{Pb}$ relative to the calc-alkaline magmas (Figure 7) that is typical for the MVB (Díaz-Bravo et al., 2014; Gomez-Tuena et al., 2007a). However, the Old Texcal Flow does not form the most radiogenic end member, but plots in the middle of the arc array near the transition between calc-alkaline and high- $\mathrm{Nb}$ series with a slight, but significant displacement toward higher ${ }^{206} \mathrm{~Pb} / 204 \mathrm{~Pb}$.

391 The $\mathrm{Sr}-\mathrm{Nd}-\mathrm{Pb}$ isotope range of the arc magmas is much more limited than that of the crustal xenoliths which represent the crustal basement (Figure 5). The arc magmas generally align better with potentially recycled crustal components, such trench sediment, AOC, the Acapulco/offshore granodiorites and biotite gneiss which either coincide or bracket the arc array. We note that the relationships between the arc magmas and the recycled components differ in all four isotope systems. For example, in $\mathrm{Sr}-\mathrm{Nd}$ isotope space, arc magmas are bracketed by AOC and trench sediment, and overlap with the Acapulco/offshore granodiorites, whereas the biotite gneiss is far more enriched than any of these components. In Nd-Hf isotope space, however, the calcalkaline and high-La arc magmas are instead bracketed by the radiogenic AOC and the unradiogenic granodiorites, respectively, while the trench sediments plots off the arc trend. In this diagram, the $\mathrm{Nb}$-rich magmas extend to slightly more unradiogenic $\mathrm{Nd}$ and Hf isotopes than the granodiorites, and the biotite gneiss is far more unradiogenic than any of these compositions. In Pb isotope space, the Cenozoic AOC and the pelagic trench sediment are less radiogenic than the arc magmas, while terrigenous sediment, granodiorites and biotite gneiss are more radiogenic. The granodiorite partially overlaps with the high- $\mathrm{Nb}$ series, but not with the calc-alkaline magmas.

\section{$408 \quad 7 . \quad$ DISCUSSION}

\section{7.1. No evidence for crustal contamination}

410 We emphasize that the new data in their entirety confirm the lack of shallow crustal 411 differentiation in the central MVB magmas (Straub et al., 2011b; 2013a; 2014). As

412 discussed earlier, and exemplified by ${ }^{143} \mathrm{Nd} /{ }^{144} \mathrm{Nd}$ in Figure 8a, the systematic increase of

413 melt silica with radiogenic isotope ratios rules out melt evolution by fractional 
414 crystallization, but links the melt silica increase to changes in source composition

415 (Gomez-Tuena et al., 2007a; Straub et al., 2013a; Straub et al., 2014). Crustal assimilation

416 (or a combination of fractional crystallization and crustal contamination), which is often

417 invoked for such correlations, however, fails in view of the ${ }^{3} \mathrm{He} /{ }^{4} \mathrm{He}-\delta^{18} \mathrm{O}$ signature of

418 the high-Ni olivines in the basaltic to andesitic magmas (Figure 4).

419 The high-Ni, high ${ }^{3} \mathrm{He} /{ }^{4} \mathrm{He}=7-8 \mathrm{R}$ olivines are either the only or first silicate phase in

420 all three magma series (calc-alkaline, high-La, and high-Nb magmas) (Schaaf et al., 2005;

421 Siebe et al., 2004a; Straub et al., 2008). As early-crystallizing olivines, they retain the

422 primary He-O isotopic signatures of the arc melts before possible later crustal

423 assimilation and secondary alteration (e.g. Eiler et al., 2000; Martelli et al., 2008). The

$424{ }^{3} \mathrm{He} /{ }^{4} \mathrm{He}$ is extremely sensitive towards crustal assimilation, but the high ${ }^{3} \mathrm{He} /{ }^{4} \mathrm{He}$ of the

425 olivines does not correlate with melt $\mathrm{SiO}_{2}$, despite as little as $0.01 \%$ mass of assimilated

426 upper crust would be sufficient to lower the melt ${ }^{3} \mathrm{He} /{ }^{4} \mathrm{He}$ below the observed range

427 (Figure 8b). This argues against crustal contamination. On the other hand, the high

$428 \delta^{18} \mathrm{O}_{\text {melt }}$ values of the olivines are clearly above mantle values regardless of the

429 fractionation correction, and point to a crustal component in the melts (Figure 8d,e).

430 While the olivine $\delta^{18} \mathrm{O}$ does not correlate with the average olivine Fo78-90 (corresponding

431 to $\mathrm{Mg} \#=53-74$ of melt) (Figure 9), it increases with increasing $\mathrm{SiO}_{2}$ of the host melts

432 (Figure $8 \mathrm{~b}$ ). The increase exceeds the $\delta^{18} \mathrm{O}$ increase predicted by fractional crystallization,

433 which agrees with results from high- $\delta^{18} \mathrm{O}$ olivine studies in the western MVB (Johnson

434 et al., 2009). This correlation cannot be attributed to crustal assimilation either, as mixing

435 of a high-Mg\#, low $\mathrm{SiO}_{2}$, low $\delta^{18} \mathrm{O}$ component (e.g. basaltic mantle melt) with low-Mg\#,

436 high $\mathrm{SiO}_{2}$, high $\delta^{18} \mathrm{O}$ crustal component predicts correlation of the $\delta^{18} \mathrm{O}$ with both melt

$437 \mathrm{SiO}_{2}$ and $\mathrm{Mg} \#$. Moreover, several tens percent of crustal material would be required in

438 order to reproduce the increase in melt $\mathrm{SiO}_{2}$ (Figure 8d), which exceeds by far any mass

439 tolerated by the ${ }^{3} \mathrm{He} /{ }^{4} \mathrm{He}$ of the olivines. Thus, if there is a crustal component in the

440 central MVB melts, it must have been added from slab. Recycled crustal material, such

441 as trench sediment or eroded crust, is initially rich in radiogenic ${ }^{4} \mathrm{He}$ and has a low

$442{ }^{3} \mathrm{He} /{ }^{4} \mathrm{He}<0.1$ (e.g., Martelli et al., 2008), but this He is driven off thermally in the

443 subduction cycle. For one, the highest closure temperature for He in common rock

444 forming minerals is $\mathrm{T}_{\mathrm{c}}=600^{\circ} \mathrm{C}$ (Martelli et al., 2008). Therefore, subducted crustal ${ }^{4} \mathrm{He}$ is

445 unlikely to survive the prolonged subduction beneath the Mexican fore-arc, where the

446 slab slowly heats up $>600^{\circ} \mathrm{C}$ before reaching ca. $700-900^{\circ} \mathrm{C}$ at arc front depth (e.g. Ferrari

447 et al., 2012; Manea and Manea, 2011). To the other, any remaining crustal He is unlikely

448 to survive heating to temperatures $>700^{\circ} \mathrm{C}$ during infiltration of the slab material into the

449 hot mantle wedge prior to melt formation. 
In summary, there is no evidence of significant crustal contamination in the basaltic and andesitic magmas at least in the olivine crystallization stage. Rather, the olivines

452 crystallize from basaltic to andesitic mantle melts that contain a crustal component from

453 the subducted slab. Remarkably, a correlation between melt silica and $\delta^{18} \mathrm{O}$ is expected

454 from the 'pyroxenite model' of melt-rock reaction that predicts the melt $\mathrm{SiO}_{2}$ abundance

455 of primary melts to increase with the amount of recycled slab component (e.g.

456 incompatible trace elements, $\delta^{18} \mathrm{O}$ ) in the mantle source (Straub et al., 2011b; 2014). Here,

457 the melting of secondary pyroxenite veins can create melt series with compositional

458 characteristics reminiscent of fractional crystallization and/or crustal assimilation

459 despite of a different genesis (Straub et al., 2014).

460 7.2. Identifying recycled slab components in $\mathrm{Sr}-\mathrm{Nd}-\mathrm{Pb}-\mathrm{Hf}$ isotope space

461 7.2.1. Constraints from $\mathrm{Sr}-\mathrm{Nd}-\mathrm{Pb}-\mathrm{H} f$ systematics

462 The ${ }^{3} \mathrm{He} /{ }^{4} \mathrm{He}-\delta^{18} \mathrm{O}$ data constrain the presence of a slab-derived crustal component in 463 the arc magmas, but they do not identify this component which could be AOC, trench

464 sediment or eroded crust, or a mixture of those. This information can be obtained

465 through comparison of arc input and output in $\mathrm{Sr}-\mathrm{Nd}-\mathrm{Pb}-\mathrm{Hf}$ isotope and trace element

466 space. To date, studies proposed that the $\mathrm{Sr}-\mathrm{Nd}-\mathrm{Pb}-\mathrm{Hf}$ isotope range of the MVB

467 magmas was a mixture of components from the subducted AOC and trench sediment,

468 and mantle wedge (e.g. Cai et al., 2014; Gomez-Tuena et al., 2007a; Straub et al., 2013a;

469 Straub et al., 2014). If this is correct, then mixing trends calculated with these end

470 members must pass through the arc data in $\mathrm{Sr}-\mathrm{Nd}-\mathrm{Pb}-\mathrm{Hf}$ isotope space. We tested this

471 inference by calculating first-order mixing curves shown in Figures 5-7. The shape of

472 isotope mixing curves depends only on the isotope and element ratios of the end

473 members, but not the concentrations of the elements (Langmuir et al., 1978). Because

474 AOC ( MORB) and the mantle wedge have similar elemental and - in first

475 approximation - also isotopic ratios, binary mixing curves between AOC and trench

476 sediment are sufficient to test the validity of the AOC-trench sediment-mantle mixing

477 models prior to full quantification. Binary first-order mixing curves were calculated with

478 measured end members given in Table 2.

479 In $\mathrm{Sr}-\mathrm{Nd}-\mathrm{Pb}$ isotope space, the arc magmas plot on, or reasonably close to,

$480 \mathrm{AOC} /$ mantle - trench sediment mixing curves (Figures 5,7). In Pb isotope space, the

481 Cenozoic AOC (average ${ }^{206} \mathrm{~Pb} /{ }^{204} \mathrm{~Pb} \sim 18.1$ ) is a better fit than the average of zero-age East

482 Pacific Rise MORB which is more radiogenic $\left({ }^{206} \mathrm{~Pb} /{ }^{204} \mathrm{~Pb} \sim 18.4\right)$ (PetDB, 2011) (Figure 7).

483 Moreover, the granodiorite and biotite gneiss emerge as possible crustal end member on

$484 \mathrm{Sr}-\mathrm{Nd}-\mathrm{Pb}$ mixing curves, together with the trench sediment. The $\mathrm{Sr}-\mathrm{Nd}-\mathrm{Pb}$ isotopic ratios 
do not distinguish between trench sediment and granodiorite/biotite gneiss crustal components. However, this seems possible in $\mathrm{Nd}-\mathrm{Hf}$ isotope space, because of the different mixing trajectories between $\mathrm{AOC} /$ mantle, trench sediment and granodiorite/biotite gneiss. Mixing curves between AOC/mantle, and trench sediment are strongly curved, because these end members have very different $\mathrm{Nd} / \mathrm{Hf}$ ratios (trench sediment $\mathrm{Nd} / \mathrm{Hf} \sim 8-20$, AOC Nd/Hf $\sim 4$, mantle $\mathrm{Nd} / \mathrm{Hf} \sim 4$ ). Therefore, these curves miss the arc magmas. However, the mixing curves between AOC/mantle and granodiorite are nearly linear and pass through most of the arc data, as the granodiorite and biotite gneiss have a similar low $\mathrm{Nd} / \mathrm{Hf} \sim 5-7$ as the $\mathrm{AOC} /$ mantle component. This is confirmed in the corresponding ${ }^{176} \mathrm{Hf} /{ }^{177} \mathrm{Hf}$ vs $\mathrm{Nd} / \mathrm{Hf}$ diagram, where mixing trends are linear. Again, the mixing lines between AOC/mantle and trench sediment, and particularly AOC/mantle - pelagic trench sediment, clearly miss the bulk of the arc data, while the granodiorite emerges as ideal crustal end member for most of the calcalkaline/high-La arc magmas, excepting only the Nb-rich magmas which extend to less radiogenic Hf ratios than the granodiorites.

The shape of the AOC-sediment Nd-Hf isotope mixing curves is affected by $\mathrm{Nd} / \mathrm{Hf}$ fractionation, which may happen during release from slab (e.g. Kessel et al., 2005). Current experimental and observational data disagree on the direction of fractionation. For example, some studies suggest that $\mathrm{Nd}$ is preferentially released in slab fluids $\left(\mathrm{D}_{\mathrm{Nd}} / \mathrm{D}_{\mathrm{Hf}}<1\right)$ at pressures of $4 \mathrm{GPa}$ or in a zircon-bearing slab (Kessel et al., 2005; Rubatto

514 Decreasing $\mathrm{Nd} / \mathrm{Hf}$ of the trench sediment causes the corresponding mixing curves to 515 pass below the arc data in the $\mathrm{Nd} / \mathrm{Hf} v s{ }^{176} \mathrm{Hf} /{ }^{177} \mathrm{Hf}$ diagram (Figure 10a,b). Increasing $516 \mathrm{Nd} / \mathrm{Hf}$ of the AOC, result the corresponding mixing curve plots above the bulk of arc 517 data (Figure 10b,c). The only exception is the high-La group that it could be fit if one of 518 the slab components had a high, fractionated $\mathrm{Nd} / \mathrm{Hf}$. 
519 In summary, the $\mathrm{Nd}-\mathrm{Hf}$ trace element and isotope systematics strongly argue for the 520 granodiorite/biotite gneiss eroded from the forearc as crustal end member in the arc 521 magmas instead of the trench sediment. The granodiorite appears the volumetrically

522 more important recycled lithology, as it seems prevalent in the ubiquitous calc-alkaline 523 series. In contrast, the biotite gneiss is much farther removed from the arc array, and fits 524 lesser well with the arc trends than the granodiorite.

\section{$525 \quad$ 7.2.2. Other slab components and processes}

526 While the high-La and $\mathrm{Nb}$-rich series are close to the calc-alkaline magmas in isotope 527 space, their trace element characteristics require additional processes and/or source 528 components. The calc-alkaline and high-La series likely involve the same source 529 materials, but the much higher $\mathrm{Nd} / \mathrm{Hf}$ of the high-La series (by up to a factor of 3) points 530 to fractionation of these elements which most likely occurs during release from slab. The 531 few high-La magmas do not form trends in $\mathrm{Nd}-\mathrm{Hf}$ isotope and trace element space and 532 thus provide no clue as which slab component - AOC or granodiorite, or a mixture of 533 both - fractionates. The fractionated nature of this slab component is consistent with 534 their other characteristics, such as the low $\mathrm{Nb}(=4-8 \mathrm{ppm})$ which is coupled with high $535 \mathrm{Nb} / \mathrm{Ta}$ (17.2-19.5) and LREE-enrichment. Arc magmas with similar signatures are 536 globally rare, but have been reported from the western MVB (Gomez-Tuena et al., 2011) 537 and the Solomon and Indonesia arcs (Goss and Kay, 2009; Koenig and Schuth, 2011; 538 Stolz et al., 1996). In either setting, these magmas have been linked to deep ( $\geq 140 \mathrm{~km})$ 539 partial melting of an fairly hot $\left(>900-1050^{\circ} \mathrm{C}\right)$ eclogitic slab that has residual rutile, but 540 lost all other REE-bearing phases like monazite and allanite (Gomez-Tuena et al., 2011; 541 Koenig and Schuth, 2011). Deep partial slab melts that escaped mingling with other slab

542 component released at shallower depths could account for the isolated eruption of high543 La in randomly distributed small $\left(<<1 \mathrm{~km}^{2}\right)$ cones remote from composite and larger 544 monogenetic volcanoes.

545 The Nb-rich magmas contain isotopically different source components, as evident 546 from their systematic differences to the calc-alkaline/high-La magmas in Sr-Nd-Pb-Hf 547 space (Figures 10-12). The similarity of the Nb-rich magmas to intraplate magmas has 548 lead to suggestions that these may derive from inherently enriched mantle domains (Cai 549 et al., 2014; Gomez-Tuena et al., 2011; Wallace and Carmichael, 1999). However, their 550 high $\delta^{18} \mathrm{O}$ and high-Ni olivines as well as details of major and trace element systematics 551 (Straub et al., 2013a) clearly point to a slab influence that is comparable in magnitude to 552 that of calc-alkaline series in most of the Nb-rich magmas. Thus, the isotopic differences 553 imply that the mantle sources of the $\mathrm{Nb}$-rich magmas were infiltrated by isotopically 
554 different slab components(s). More than one factor, however, is responsible for the 555 isotopic differences. One factor is that the calc-alkaline/high-La series are more hydrous

556 than the $\mathrm{Nb}$-rich series, having several $\mathrm{wt} \%$ melt water compared to $\leq 1 \mathrm{wt} \%$ of the $\mathrm{Nb}$ -

557 rich magmas (e.g. Cervantes and Wallace, 2003a; Johnson et al., 2009; Roberge et al.,

558 2009). Thus, and consistent with previous models (e.g. Gomez-Tuena et al., 2007a; Straub

559 et al., 2014), the source of the calc-alkaline/high-La series seems to receive more slab

560 fluids, such as $\mathrm{Sr}$-and $\mathrm{Pb}$-rich fluids (or possibly hydrous melts) from AOC. An AOC

561 fluid rich in the unradiogenic $\mathrm{Pb}$ of the Cenozoic MORB-type crust may shift the calc-

562 alkaline/high-La magmas towards lesser radiogenic $\mathrm{Pb}$ isotope ratios relative to the

563 high- $\mathrm{Nb}$ magmas in $\mathrm{Pb}$ isotope space (Figure 12). AOC fluids may also carry $\mathrm{Sr}$ with a

$564{ }^{87} \mathrm{Sr} /{ }^{66} \mathrm{Sr}$ higher (up to $\sim 0.705$, Staudigel et al., 1995) than that fresh MORB $\left({ }^{87} \mathrm{Sr} /{ }^{86} \mathrm{Sr} \sim 0.702-\right.$

5653 3) of AOC, and shift the calc-alkaline/high-La magmas towards higher ${ }^{87} \mathrm{Sr} /{ }^{86} \mathrm{Sr}$ at a given

$566{ }^{143} \mathrm{Nd} /{ }^{144} \mathrm{Nd}$ (Figure 11) (e.g. Gomez-Tuena et al., 2007a; 2013a; Straub et al., 2014).

567 A fractionated fluid component that is enriched in fluid mobile LILE relative to the

568 HFSE does not account for the trace element budget of the Nb-rich magmas. Instead, the

569 slab component infiltrating the source of the $\mathrm{Nb}$-rich magmas must be rich in $\mathrm{Nb}$ and

$570 \mathrm{Ta}$, and have high $\mathrm{Nb} / \mathrm{Ta}$ (16-19.4), high $\mathrm{Nb} / \mathrm{La}(\sim 0.9)$, low Th/La (0.11) and the low

$571 \mathrm{Nd} / \mathrm{Hf}(\sim 4)$. This rules out the granodiorites or similar crustal material as source as this

572 material has fractionated trace element signatures which it would transmit to the mantle

573 (Appendix Figure 2). On the other hand, intraplate basalts have the requisite isotope and

574 trace signatures (e.g. Hofmann, 2003). We tentatively suggest that the source of the high-

$575 \mathrm{Nb}$ magmas may have been infiltrated by crust constructed by intraplate seamount

576 magmas. It is possible that such seamount crust was part of the largely inaccessible

577 continental fore-arc basement. Alternatively, it could be part of subducting Cocos plate

578 where clusters of intraplate seamounts are common (e.g. Bohrson and Reid, 1995;

579 Castillo et al., 2010; Niu and Batiza, 1997). Local recycling of seamount material,

580 mingling to some extent with granodiorite, could account for the limited distribution of

581 the $\mathrm{Nb}$-rich magmas in space and time in the Sierra Chichinautzin (Straub et al., 2013b)

582 as well as along the volcanic front of the entire MVB.

\section{7.3. Magnitude and impact of the eroded crust on arc magmas}

584 The granodiorite emerges are important component in the arc magmas. In order to

585 quantitatively assess its influence, we used a combination of inverse methods (trace

586 elements) and forward modeling techniques (radiogenic isotopes). This two-fold

587 approach minimizes the inherent uncertainties of flux quantification where many

588 variables are model-dependent. 


\subsubsection{Estimating the total slab flux from trace elements}

590 First, we estimated the total percentage of slab-derived $\mathrm{Sr}, \mathrm{Pb}, \mathrm{Nd}$ and $\mathrm{Hf}$ in the arc

591 magmas by the inverse method of Pearce et al. (1995a). The method calculates the

592 difference for each sample between the observed concentration of an element - which is

593 that of a melt from the subduction-modified mantle - and its concentration in a

594 hypothetical melt from the same mantle free from slab additions ('background mantle').

595 These differences then scale to the percentage of the slab-derived element in the arc

596 magmas. Assuming $\mathrm{Nb}$ and $\mathrm{Yb}$ to be mantle-derived, Pearce et al. (1995a) used $\mathrm{Nb} / \mathrm{Yb}$

597 ratios to calculate the 'background magma'. In the central MVB, however, $\mathrm{Nb}$ is added

598 from slab, and hence $\mathrm{TiO}_{2} / \mathrm{Lu}$ is used (Straub et al., 2013a; 2014). Moreover, instead of

599 MORB-type mantle source (Pearce et al., 1995a), we used primitive mantle for

600 calculating the slab-derived percentages for the high-Nb magmas, and residual

601 primitive mantle (after 3.5\% melt extraction) calculating those of the calc-alkaline and

602 high-La magmas. Only with magmas with $\mathrm{Mg} \#>60$ were used in order to ensure the use

603 of trace element ratios in the most primitive magmas.

604 The trace element inversion confirms a strong slab flux of $\mathrm{Sr}, \mathrm{Nd}, \mathrm{Pb}$ and $\mathrm{Hf}$ for all

605 three arc magma series, with the $\mathrm{Nb}$-rich magmas ( $>44-59 \%$ of $\mathrm{Sr}, \mathrm{Nd}, \mathrm{Pb}$ and $\mathrm{Hf}$ slab-

606 derived) having about one third less slab contribution than the calc-alkaline (>69-89\%)

607 and high-La series (73-96\%) (Table 1). In Figure 13, the slab-derived percentages are

608 plotted against the relevant isotopic composition. The Old Texcal Flow is always the

609 least influenced by the slab flux (slab-derived $\mathrm{Pb} \sim 18 \%$, $\mathrm{Sr} \sim 34 \% \mathrm{Nd} \sim 16 \% \mathrm{Hf} \sim 20 \%$ ) and

610 forms a common point of origin from which the trends of calc-alkaline/high-La and

611 high-Nb magmas diverge towards different slab components. These trends agree with a

612 model of a homogenous mantle that was infiltrated by at least two isotopically distinct

613 slab components. Remarkably, there are no clear trends towards the trench sediment,

614 which confirms its negligible influence on the arc magmas. This is most evident for the

615 arc Sr that must principally originate from recycled AOC and/or granodiorite, without

616 any apparent contribution of sedimentary Sr. Another feature is that none of the arc

617 trends heads towards the same, or the same mix, of slab components in all four isotope

618 systems. This supports the concept of the slab flux being a composite of several

619 individual components that mix in variable proportions.

$620 \quad$ 7.3.2. Quantifying the slab sources in isotope space

621 Forward mixing models in isotope space allow for the estimation of the individual 622 contributions of mantle and slab components to the arc magmas. The first step is to fit 623 mixing curves through the arc data with the appropriate end members (mantle, AOC, 
624 granodiorite/seamounts). A model curve is valid if (i) it passes through the data, and (ii)

625 the modeled elemental ratios reasonably reproduce those of the magmas. We first used

626 the measured elemental ratios of the end members (Table 2). If the mixing curve did not

627 pass through the arc data, then the elemental ratios of the slab-derived end members

628 were modified based on the results from experimental studies.

629 Suitable mixing curves can be generated in $\mathrm{Nd}-\mathrm{Hf}-\mathrm{Pb}$ isotope space without problem

630 (Figures 10,12). In $\mathrm{Sr}-\mathrm{Nd}$ isotope space, however, the $\mathrm{Sr} / \mathrm{Nd}$ of the slab component needs

631 to be adjusted in order to reproduce the high $\mathrm{Sr} / \mathrm{Nd}$ of the arc magmas (calc-

632 alkaline/high-La series $\mathrm{Sr} / \mathrm{Nd} \sim 25 \pm 4 ; \mathrm{Nb}$-rich magmas $\mathrm{Sr} / \mathrm{Nd} \sim 19 \pm 4$ ). This exceeds those of

633 the main sources (mantle $\sim 12-16$, AOC $\sim 12$, granodiorite $\sim 9$, intraplate seamounts $\sim 13$ ).

634 Mixing curves were fitted by increasing the AOC Sr by a factor of 2.5 for the Nb-rich

635 magmas. For the calk-alkaline series, the Sr flux was increased by a factor of 3 for

636 granodiorite and 4 for AOC. While these adjustments are somewhat arbitrary, they

637 provide a measure of the magnitude of the required Sr excess from slab. The final

638 isotope and elemental ratios of the end members are given in Table 2.

639 For the calculation of the $\mathrm{Sr}-\mathrm{Nd}-\mathrm{Pb}-\mathrm{Hf}$ mixing curves, compositions of idealized,

640 average end member are used (Figures 10-12). While mantle, AOC and granodiorite

641 compositions are reasonably well known (Table 2), the composition of the inferred

642 recycled seamount component is unknown, and therefore its quantification is tentative.

643 For an estimate, we used the $\mathrm{Sr}, \mathrm{Nd}, \mathrm{Pb}$ and $\mathrm{Hf}$ abundances of off-axis seamounts with

$644 \mathrm{Nb}>13-46$ ppm from Niu and Batiza (1997), and estimated the isotope ratios of end

645 members from the $\mathrm{Sr}-\mathrm{Nd}-\mathrm{Pb}-\mathrm{Hf}$ isotope mixing systematics of the arc magmas.

646 Two different types of background mantle were chosen: a primitive mantle for the

$647 \mathrm{Nb}$-rich magmas, and a residuum of primitive mantle after 3.5\% melt extraction for the

648 calc-alkaline and high-La series (Table 2). The elemental abundances and ratios of the

649 slab components vary considerably depending on whether the slab material is released

650 as bulk component ('slab diapir'), or as partial fluid or melt. Forward estimates are thus

651 inherently uncertain because these depend on a multitude of often poorly known

652 variables (e.g. metamorphic history of slab, partition coefficients, mixing proportions,

653 slab residual mineralogy, thermal structure and composition, physical properties).

654 Again, we choose the simplest approach by using the measured elemental abundances

655 of the end members, with only the abundance adjustment for $\mathrm{Sr}$ (Table 2). This approach

656 minimizes the calculated influence of the slab flux on the arc magmas. In addition,

657 mixing proportions were chosen to minimize the contributions of granodiorite. In Sr-

$658 \mathrm{Nd}-\mathrm{Hf}$ isotope space, the arc data can be reproduced with a slab component composed 
of $50 \% \mathrm{AOC}$ and $50 \%$ granodiorites (or seamount material for the high- $\mathrm{Nb}$ magmas).

660 The same mixing ratio is valid for the AOC-seamount slab component in $\mathrm{Pb}$ isotope

661 space. The granodiorites, however, are so enriched in $\mathrm{Pb}$ relative to mantle and $\mathrm{AOC}$

662 that only $10 \%$ in the slab component is needed to reproduce the data. A $20 \%$ of the

663 composite slab component was mixed with the mantle wedge, which is consistent with

664 major and trace element constrained from previous studies (Straub et al., 2011b; 2013a;

665 2014). Modeling parameters are given in Table 2, and the results are summarized in

666 Table 3.

667 In summary, the isotope models suggest (within model uncertainty) a slab flux similar

668 in magnitude to results to that produced by the trace element inversion with the

669 exception of $\mathrm{Hf}$ (Tables 1 and 3). Slab-derived percentages are for $\mathrm{Sr} \sim 78-96 \%$ (compared

670 to $49-95 \%$ from trace element inversion), for $\mathrm{Pb} \sim 76-86 \%$ (59-96\% from inversion), for $\mathrm{Nd}$

$671 \sim 76-87 \%$ (47-93\% from inversion) and for $\mathrm{Hf} \sim 75-87 \%$ (44-73\% from inversion). The

672 significant observation is the high slab contribution relative to that of the mantle wedge,

673 and in particular that of the granodiorite. The granodiorite controls the isotope

674 chemistry of the calc-alkaline magmas/high-La, to which they supply most of the $\mathrm{Sr}$

$675 \sim 73 \%, \mathrm{~Pb} \sim 61 \%, \mathrm{Nd} \sim 68 \%$ and $\mathrm{Hf} \sim 87 \%$. Likewise, the purported seamount component

676 makes a strong, but somewhat lesser contribution to the Nb-rich magmas ( $\mathrm{Sr} \sim 37 \%, \mathrm{~Pb}$

$677 \sim 54 \%, \mathrm{Nd} \sim 51 \%$ and $\mathrm{Hf} \sim 46 \%$ ) relative to mantle and AOC. The overall contributions of

678 the AOC fluids to the arc magmas are fairly low, with only $\mathrm{Sr} \sim 23-42 \%, \mathrm{~Pb} \sim 22-25 \%$, Nd

$679 \sim 21-25 \%$ and $\mathrm{Hf} \sim 27-28 \%$. Even if contribution of the $\mathrm{Pb}$ AOC is likely underestimated,

680 as the model makes no allowance for Pb enrichment in AOC fluids, the moderate

681 influence of AOC-derived $\mathrm{Pb}$ on the arc $\mathrm{Pb}$ isotope ratios agrees with their lack of

682 isotopic overlap with AOC, which is unlike many other arcs where the influence of AOC

683 components is much stronger (Figures 11, 12) (e.g. Straub and Zellmer, 2012). Overall,

684 the modeling results imply a strong influence of eroded granodiorite on the calk-alkaline

685 and high-La magmas, while the $\mathrm{Nb}$-rich magmas are influenced to similar extent by

686 another slab component (possibly seamounts).

687 7.4. Why does the trench sediment align with the MVB magmas in Sr-Nd-Pb 688 isotope space?

689 The Acapulco/offshore granodiorites, possibly complemented by an unknown

690 seamount component, provide an excellent recycled crustal component for the MVB

691 magmas, but the question remains why the trench sediments align so well with the arc

692 magmas in $\mathrm{Sr}-\mathrm{Nd}-\mathrm{Pb}$ isotope space? A simple answer may be that trench sediment and

693 arc magmas are essentially mixtures of the same, or similar, components from 
694 continental crust and MORB. The arc magmas, however, form by mixing of these

695 components in the mantle, whereas the sediments form by mixing on the Earth' surface.

696 Marine sediment is essentially the debris of continental erosion (lithogenic dust, volcanic

697 ash, riverine and hemipelagic input) that is diluted by biogenic components in the

698 oceans (Plank, 2004; Plank and Langmuir, 1998; Vervoort et al., 2011). The sediment

$699{ }^{87} \mathrm{Sr} /{ }^{86} \mathrm{Sr}$ and ${ }^{143} \mathrm{Nd} /{ }^{144} \mathrm{Nd}$ is controlled by $\mathrm{Nd}$ - and Sr-rich debris and dust from the North

700 American continent, and is similar in pelagic and terrigenous sediments. The continental

701 debris also controls the $\mathrm{Pb}$ isotope composition of the sediments, but close to mid-ocean

702 ridges the continental signal is overprinted by MORB-type $\mathrm{Pb}$ delivered by

703 hydrothermal fluids. Thus, only the terrigenous sediment $(\mathrm{Pb}=21 \mathrm{ppm})$ reflects the $\mathrm{Pb}$

704 isotopes of the continental crust, whereas the $\mathrm{Pb}$-rich pelagic sediment $(\mathrm{Pb}=66 \mathrm{ppm}$

705 LaGatta, 2003) is displaced towards the unradiogenic Pb typical of Cenozoic MORB. In

706 Nd-Hf isotope and trace element space, however, sediment does not align with crust-

707 mantle trends, because of fractionation during transport from the continent. For

708 example, early loss of Hf-rich heavy minerals in rivers (e.g. zircon) increases the $\mathrm{Nd} / \mathrm{Hf}$

709 ratio of the suspended load, and hydrothermal fluids may change the $\mathrm{Nd}$ and Hf isotope

710 ratios of the continental debris (e.g. Garcon et al., 2013; Garçon et al., 2014; Vervoort et

711 al., 2011). Thus, the Nd-Hf isotope and trace element signature of the continental crust is

712 different from the trench sediment, allowing their signatures to be discriminated in the

713 arc magmas.

\section{$714 \quad$ 7.5. Recycling by slab diapirism - a physical model}

\section{7.5.1. Estimating the amount of eroded recycled crust}

716 A significant outcome of our study is that the trench sediment does not influence the 717 central MVB arc magmas. However, there is no evidence for sediment accumulation in

718 the trench, and all trench sediment seems to have been subducted (Manea et al., 2003).

719 Consequently, the signal of the trench sediment in the calc-alkaline arc magmas must be

720 concealed by the eroded granodiorite. We estimated the minimum amount of

721 granodiorite needed to conceal the trench sediment from the $\mathrm{Nd}$ and $\mathrm{Hf}$ fluxes. The

722 volume of the trench sediment is $\sim 8.84 \mathrm{~km}^{3} / \mathrm{km} / \mathrm{Myr}$, at a convergence rate of 52

$723 \mathrm{~km} /$ Myr, thickness of $170 \mathrm{~m}$ (Plank, 2014), density of $1370 \mathrm{~kg} / \mathrm{m}^{3}$ and water content of 59

$724 \mathrm{wt} \%$. Thus, it supplies $\mathrm{Nd}=169.3 \mathrm{~g} / \mathrm{km} / \mathrm{Myr}$ and $\mathrm{Hf}=10.6 \mathrm{~g} / \mathrm{km} / \mathrm{Myr}$ with an average

$725 \mathrm{Nd} / \mathrm{Hf}=16$ [based on Plank (2014)]. A similar thickness of granodiorite with a density of

$7262700 \mathrm{~kg} / \mathrm{m}^{3}$ and zero water content would supply $\mathrm{Nd}=782.9 \mathrm{~g} / \mathrm{km} / \mathrm{Myr}$ and $\mathrm{Hf}=136.0$

$727 \mathrm{~g} / \mathrm{km} / \mathrm{Myr}$ with an average $\mathrm{Nd} / \mathrm{Hf}=5.8$. Therefore, in order to generate $\mathrm{Nd} / \mathrm{Hf}<6$ of the

728 total recycled crustal component, the mass of eroded crust must exceed that of the trench 
sediment by at least 9-10 times. This corresponds to a minimum rate of recycled granodiorite of $\sim 79-88.4 \mathrm{~km}^{2} / \mathrm{Myr}$.

731 This estimate exceeds by more than two times the estimate of Ducea et al. (2004) who

732 inferred one-dimensional exhumation rates of $0.18 \mathrm{~km} / \mathrm{Myr}$ from (U-Th)/He

733 thermochronology of the south central Mexican basement, and estimated $\sim 30$

$734 \mathrm{~km}^{3} / \mathrm{km} / \mathrm{Myr}$ crustal loss by subduction during the Miocene. On the other hand, our

735 estimate compares well with the numbers derived from the reconstruction of the shape

736 of the missing Eocene to Miocene fore-arc. The unusual location of the MVB at $360 \mathrm{~km}$

737 from the trench has been interpreted as the result of a process of slab flattening between

738 middle and late Miocene (Ferrari et al., 1999). Thus, the pre-Miocene arc location is

739 inferred from the configuration of the general Rivera-Cocos subduction, where the arc is

$740 \sim 150 \mathrm{~km}$ from the trench in the Jalisco-Colima region, but between 150 and $200 \mathrm{~km}$ from

741 the trench in Guatemala. At fore-arc crustal thickness of $20 \mathrm{~km}$ (Kim et al., 2010), the

742 crustal loss would be between $20 \times 150 \mathrm{~km}^{2}=3000 \mathrm{~km}^{2}$ and $20 \times 200 \mathrm{~km}^{2}=4000 \mathrm{~km}^{2}$. Given the

$743 \sim 50 \mathrm{Ma}$ age of batholiths of the Acapulco coast (Hernández-Pineda et al., 2011), and a

744 17 Ma start of the MVB volcanic activity (Gómez-Tuena et al., 2007b), this yields an

745 average rate of $60-80 \mathrm{~km} / \mathrm{km} / \mathrm{Myr}$ for the last in $50 \mathrm{Ma}$. Thus, our estimate can be

746 considered as realistic.

\section{7.5.2. Granodiorite recycling by slab diapirism}

748 The high rate of recycled granodiorite has consequences for the style of mass transfer

749 from slab to wedge. Assuming the subducted granodiorite to be $\sim 9-10$ times thicker than

750 trench sediment ( $=170 \mathrm{~m}$ thick), it would reach a thickness of $\sim 1500-1700$ meters.

751 Together with the typical low density of a quartz-feldspar lithology $\left(2700 \mathrm{~kg} / \mathrm{m}^{3}\right)$ and the

752 estimated slab temperatures below the arc front of $\sim 700-900^{\circ} \mathrm{C}$ (Ferrari et al., 2012;

753 Manea and Manea, 2011), these are ideal conditions for buoyant detachment of the

754 granodiorite from slab as 'slab diapirs' without need for slab melting (Behn et al., 2011;

755 Gerya et al., 2004; Gómez-Tuena et al., 2014; Hacker et al., 2011). Such slab diapirs are a

756 highly efficient way to transfer large amounts of slab material into the mantle wedge.

757 Silicic diapirs can react with the peridotite in similar ways as perceived for silicic slab

758 fluids or melts, and form secondary pyroxenites. Importantly, as the granodiorite has

759 similar low average $\mathrm{Ho} / \mathrm{Lu}=2.5 \pm 0.5$ as the mantle wedge $(\mathrm{Ho} / \mathrm{Lu} \sim 2.2)$, it will not

760 impose a garnet signature on the mantle either.

761 A recycling cartoon is shown in Figure 14. The granodiorite is depicted to rise

762 buoyantly in the form of diapirs without melting. It may have little intrinsic water, but

763 water could be added from the dewatering AOC, as well as from serpentinite lithologies 
764 from within and below the AOC (e.g. Gómez-Tuena et al., 2014). The granodiorite

765 diapirs dominate by far the slab flux, and are complemented by deep slab melts may

766 form at $>140 \mathrm{~km}$ and infiltrate the source of the high-La magmas. The high- $\mathrm{Nb}$ magmas

767 are tentatively interpreted to be recycled intraplate seamount crust that is entrained into

768 the granodiorite diapirs. All slab components rise into the hot interior of the mantle

769 wedge where they react with the peridotite to form pyroxenite segregations that then

770 melt in the upwelling mantle, and mix during ascent through mantle and crust. The

771 numerous, closely spaced, but compositionally highly diverse small volume

772 monogenetic volcanoes $\left(\leq 1 \mathrm{~km}^{3}\right)$ may be the surface expressions of a heterogeneous sub-

773 arc mantle interspersed with pyroxenite veins. On the other hand, a succession of

774 individual slab diapirs channelized at a preferred spot of over a longer period of time

775 (several $100 \mathrm{ka}$ to 1 million years), may ultimately accumulate the eruptive volumes of

776 several $100 \mathrm{~km}^{3}$ typical of the composite volcanoes (e.g. Gómez-Tuena et al., 2014).

777 7.6. The impact of subduction erosion on the central MVB magmas

778 Our recycling model implies that the slab flux controls the budget of the highly

779 incompatible elements in the arc magmas. We tested this inference by means of the

780 incompatible element ratios $\mathrm{Th} / \mathrm{La}$ and $\mathrm{Nb} / \mathrm{Ta}$, that are difficult to fractionate during

781 subduction processing (e.g. Foley et al., 2002; Plank, 2004). Th/La ratios (=0.09 to 0.37)

782 span the global range from the low Th/La ( 0.05) of the mantle to the high Th/La ( 0.37)

783 of upper continental crust (e.g. Plank, 2004; Rudnick and Gao, 2002). The range of $\mathrm{Nb} / \mathrm{Ta}$

$784(=12.3-19.5)$ is similarly broad, and only excludes the rare, supercondritic $\mathrm{Nb} / \mathrm{Ta}>19.9$

785 reported from some arcs (Gomez-Tuena et al., 2011; Koenig and Schuth, 2011; Stolz et al.,

786 1996) (Figure 15).

787 Mixing relationships with ${ }^{143} \mathrm{Nd} /{ }^{144} \mathrm{Nd}$ confirm that the $\mathrm{Th} / \mathrm{La}$ and $\mathrm{Nb} / \mathrm{Ta}$ of the calc-

788 alkaline series is inherited from the inherently heterogeneous granodiorite. The

789 granodiorites form a perfect end member that would buffers the MVB magmas at high

$790{ }^{143} \mathrm{Nd} /{ }^{144} \mathrm{Nd}$ and at a broader range of $\mathrm{Th} / \mathrm{La}$ and $\mathrm{Nb} / \mathrm{Ta}$. Some granodiorites also have

791 the low $\mathrm{Th} / \mathrm{La}$ and high $\mathrm{Nb} / \mathrm{Ta}$ intrinsic to the high-Nb magmas. However, oceanic

792 seamounts have the same characteristics and provide a more likely end member given

793 their isotopic and trace element composition (Figure 15).

794 The strong influence of the various recycled components on MVB melt chemistry is

795 best evident in $\mathrm{Nb}$ vs $\mathrm{Nb}$ /Ta space (Figure 16). The Old Texcal Flow (proxy to melt from

796 mantle wedge prior to subduction modification) divides this diagram into four

797 quadrants. The high-La magmas all plot in the upper left quadrant which combines high

$798 \mathrm{Nb} / \mathrm{Ta}>17$ with low $\mathrm{Nb}$ concentrations typical of a signature of deep melts from eclogitic 
slabs with residual rutile (Gomez-Tuena et al., 2011; Koenig and Schuth, 2011). The high-

$800 \mathrm{Nb}$ series occupy quadrant II with their combination of high $\mathrm{Nb}$ and $\mathrm{Nb} / \mathrm{Ta}$ being

801 tentatively attributed to the recycling of seamount material. The calc-alkaline magmas

802 (quadrant III), have the low $\mathrm{Nb}$ and $\mathrm{Nb} / \mathrm{Ta}(\sim 12-16)$ typical of continental crust material,

803 here recycled by subduction erosion. Calc-alkaline magmas with these characteristics

804 dominate the entire MVB volcanic front (2014; Gómez-Tuena et al., 2007b). Previous

805 studies linked the low arc $\mathrm{Nb} / \mathrm{Ta}$ to the partial melting of an amphibole-bearing slab, as

806 amphibole is the only major slab phase that can retain $\mathrm{Nb}$ relative to $\mathrm{Ta}$, and produces

807 slab melts with low $\mathrm{Nb}$ and $\mathrm{Nb} / \mathrm{Ta}$ (Foley et al., 2002; Gomez-Tuena et al., 2007a; Gomez-

808 Tuena et al., 2011; Koenig and Schuth, 2011). However, most of the MVB arc front is

809 located $>80 \mathrm{~km}$ above the slab and thus beyond the amphibole-eclogite transition

810 (Tatsumi and Eggins, 1995). Here, regardless of amphibole stability, recycling of pre-

811 existing continental crust with intrinsically low- $\mathrm{Nb} / \mathrm{Ta}$ provides a simpler cause for the

812 predominantly low $\mathrm{Nb} / \mathrm{Ta}$ of MVB magmas.

813 Likewise, if the granodiorite transmits the high $\mathrm{Th} / \mathrm{La}$ to the calc-alkaline series, there

814 is no need for additional $\mathrm{Th} / \mathrm{La}$ fractionation of the magmas, either during slab

815 processing (e.g. Cai et al., 2014) or by shallow crustal differentiation (e.g. Plank, 2004).

816 Additional $\mathrm{Th} / \mathrm{La}$ fractionation is only needed if all source components had lower $\mathrm{Th} / \mathrm{La}$

817 than the arc. While AOC, mantle wedge and average trench sediment all have low $\mathrm{Th} / \mathrm{La}$

818 (Cai et al., 2014), the granodiorite ( $\mathrm{Th} / \mathrm{La}=0.25 \pm 0.10)$ has similar high and variable $\mathrm{Th} / \mathrm{La}$

819 as the calc-alkaline arc magmas $(=0.21 \pm 0.06)$. Here, our results support the crustal

820 recycling model of Plank (2004) who proposed that the high Th/La in global arcs is

821 essentially inherited from perpetual recycling of continental crust via the trench

822 sediment ( upper continental crust, Plank and Langmuir, 1998) and expand it to include

823 continental crust recycled by subduction erosion.

824 There are other compositional features that the calc-alkaline central MVB may inherit

825 from granodiorite. The low $\mathrm{Sr} / \mathrm{Y} \sim 11$ of the granodiorite, regardless of additional $\mathrm{Sr}$ from

826 AOC fluids, appears to control the low $\mathrm{Sr} / \mathrm{Y}$ of the arc magmas $(<50)$. This explains the

827 absence of 'adakitic' high $\mathrm{Sr} / \mathrm{Y}>50$ in the central MVB that has been considered as arc

828 with a 'young and hot' slab prone to melting in previous studies (e.g. Cai et al., 2014;

829 Defant and Drummond, 1990). The granodiorites may also buffer the $\mathrm{Ba}, \mathrm{Rb}, \mathrm{Ba}$ and $\mathrm{Pb}$

830 abundances on the arc to their comparatively low abundances, which are too low if the

831 arc input would be made up AOC and the trench sediment that is highly enriched in

832 these elements (Gomez-Tuena et al., 2007a). Overall, the central MVB poses an excellent

833 example for a volcanic arc that may principally grow by recycling of pre-existing 
834 continental crust rather than through the creation of new arc crust by subduction

835 processing.

\section{8. CONCLUSIONS}

837 The following are the conclusions of this study:

838 (1) The Nd-Hf isotope and trace element systematics of central Mexican arc magmas

839 identify granodiorites eroded from the continental fore-arc, and not trench

840 sediment, as the principal recycled component of continental crust.

841 (2) The calc-alkaline arc magmas of the central MVB ( $>95 \%$ of the erupted volume) are 842 mixtures of recycled granodiorite, subducted AOC and mantle wedge. Rare,

843 strongly fractionated high-La magmas, and a minor group of $\mathrm{Nb}$-rich magmas, can

844 be linked to deep slab melting, and the local recycled of seamount material,

845 respectively.

846 (3) With an estimated mass flux of $79-88 \mathrm{~km}^{3} / \mathrm{km} / \mathrm{Myr}$, thickness of $1500-1700 \mathrm{~m}$ and

847 density of $2700 \mathrm{~kg} / \mathrm{m}^{3}$, the eroded granodiorite layer is conducive to the buoyant

848 ascent from slab in form of 'slab diapirs', with no need for slab melting, at the

849 estimated slab temperatures of $700-900^{\circ} \mathrm{C}$.

850 (4) $\mathrm{Th} / \mathrm{La}, \mathrm{Nb} / \mathrm{Ta}$ and other key trace element ratios of the calc-alkaline magmas are 851 inherited from the granodiorite, suggesting that the MVB arc grows by recycling of 852 the continental crust rather than by formation of new continental crust.

\section{$8549 . \quad$ ACKNOWLEDGEMENTS}

855 Special thanks to Der-Chuen Lee, Wen-Yu Hsu and Kuo-Lung Wang for help with Hf 856 separation and isotope analysis at the Institute of Earth Sciences at Academia Sinica 857 (Taipei/Taiwan), and to Ofelia Pérez-Arvizu for help with isotope and trace element 858 analyses at Lamont and the UNAM Centro de Geociencias/Queretaro, Mexico, and to 859 Charlie Langmuir, Terry Plank and Catherine Chauvel for discussion. Vincente Loreto

860 Becerra, Jesús Valenzuela González, Hermes Samir Herrera Fernández and Sergio Nuño

861 Licona provided valuable support in the field. Yue Cai is thanked for help with isotope

862 separation procedures at Lamont. Catherine Chen, Ellen Knapp, Rose Ramirez and

863 Maggie Sochko assisted with sample preparation. Four anonymous reviewers and

864 Associate Editor Andreas Stracke are thanked for their constructive comments. The

865 IODP Gulf Coast Repository/TX provided the samples from DSDP Leg 66 and IODP

866 Legs 320/321. Support from National Science Foundation grants EAR-07-38707 and EAR- 


\section{REFERENCES CITED}

Agustín-Flores, J., Siebe, C., Guilbaud, M.N., 2011. Geology and geochemistry of Pelagatos, Cerro del Agua, and Dos Cerros monogenetic volcanoes in the Sierra Chichinautzin Volcanic Field, south of México City. J Volcanol Geotherm Res 201 143-162, doi:110.1016/j.jvolgeores.2010.1008.1010.

Auer, A., Bindeman, I.N., Wallace, P.J., Ponomareva, V., Portnyagin, M., 2009. The origin of hydrous, high- $\delta^{18} \mathrm{O}$ voluminous volcanism: diverse oxygen isotope values and high magmatic water contents within the volcanic record of Klyuchevskoy volcano, Kamchatka, Russia Contrib Mineral Petrol 157.

Behn, M.D., Kelemen, P.B., Hirth, G., Hacker, B.R., Massonne, H.J., 2011. Diapirs as the source of the sediment signature in arc lavas. Nat Geoscience 4, doi: 10.1038/NGEO1214.

Bindeman, I., 2008. Oxygen Isotopes in Mantle and Crustal Magmas as revealed by Single Crystal analysis. Rev Mineral Geochem 69, 445-478, doi: 410.2138/rmg.2008.2169.2112.

Blatter, D.L., Carmichael, I.S.E., Deino, A.L., Renne, P.R., 2001. Neogene volcanism at the front of the central Mexican volcanic belt: basaltic andesites to dacites, with contemporaneous shoshonites and high-TiO2 lavas. Geol Soc Am Bull 113, 1324-1342.

Bohrson, W.A., Reid, M.R., 1995. Petrogenesis of alkaline basalts from Socorro Island, Mexico: Trace element evidence for contamination of ocean island basalt in the shallow ocean crust J Geophys Res 100, 24555-24576.

Brandl, P.A., Regelous, M., Beier, C., Haase, K.M., 2011. Chemical Evolution of the Oceanic Crust on 103 - 108 Year Timescales, AGU Fall Meeting, San Francisco, pp. T31A-2327.

Brandl, P.A., Regelous, M., Beier, C., O'Neill, S.C., O, N., Haase, K.M., 2015. The chemical stratigraphy of the extrusive oceanic crust: timescales of magma evolution at mid-ocean ridges. submitted to Lithos.

Cai, Y., 2009. Tracing Upper Mantle Heterogeneities with radiogenic isotopes at the Mexican Volcanic Belt and the Arctic Gakkel Ridge, Graduate School of Art and Philosophy. Columbia University, New York, p. 243p.

Cai, Y., LaGatta, A., Goldstein, S.L., Langmuir, C.H., Gomez-Tuena, A., Martin del Pozzo, A.L., Carrasco-Nunez, G., 2014. Hafnium isotope evidence for slab melt contributions in hot slab arcs: an example of the Central Mexican Volcanic Belt. Chem Geol 377, 45-55, http://dx.doi.org/10.1016/j.chemgeo.2014.1004.1002.

Carpentier, M., Chauvel, C., Mattielli, N., 2008. Pb-Nd isotopic constraints on sedimentary input into the Lesser Antilles arc system. Earth Planet Sci Lett 272, 199-211, doi:110.1016/j.epsl.2008.1004.1036.

Castillo, P.R., Clague, D.A., Davis, A.S., Lonsdale, P.F., 2010. Petrogenesis of Davidson Seamount lavas and its implications for fossil spreading center and intraplate magmatism in the eastern Pacific. G-cubed 11, doi: 10.1029/2009GC002992.

Cervantes, P., Wallace, P.J., 2003a. The role of $\mathrm{H} 2 \mathrm{O}$ in subduction zone magmatism: New insights from melt inclusions in high-Mg basalts from central Mexico. Geochim Cosmochim Acta 31, 235-238. 
Clift, P.D., Vannucchi, P., 2004. Controls on Tectonic Accretion versus Erosion in Subduction 
958

Gomez-Tuena, A., Langmuir, C.H., Goldstein, S.L., Straub, S.M., Ortega-Gutierrez, F., 2007 a. Geochemical Evidence for Slab Melting in the Trans-Mexican Volcanic Belt. J Petrol 48, 537562, doi:510.1093/petrology/eg11071.

Gomez-Tuena, A., Laura Mori, L., Goldstein, S.L., Perez-Arvizu, O., 2011. Magmatic diversity of western Mexico as a function of metamorphic transformations in the subducted oceanic plate. Geochim Cosmochim Acta 75 213-241, doi:210.1016/j.gca.2010.1009.1029.

Gómez-Tuena, A., Mori, L., Rincón-Herrera, N.E., Ortega-Gutiérrez, F., Solé, J., Iriondo, A., 2008. The origin of a primitive trondhjemite from the Trans-Mexican Volcanic Belt and its implications for the construction of a modern continental arc. Geochim Cosmochim Acta 36, 471-474, doi: 410.1130/G24687A.

Gómez-Tuena, A., Orozco-Esquivel, M.T., Ferrari, L., 2007b. Igneous petrogenesis of the TransMexican Volcanic Belt, in: Alaniz-Álvarez, S.A., Nieto-Samaniego, Á.F. (Eds.), Geology of México: Celebrating the Centenary of the Geological Society of México: Geological Society of America Special Paper.

Gomez-Tuena, A., Straub, S.M., Zellmer, G.F., 2014. An introduction to orogenic andesites and crustal growth in: Gomez-Tuena, A., Straub, S.M., Zellmer, G.F. (Eds.), Orogenic andesites and crustal growth Geological Society of London, London, pp. 1-13, doi:10.1144/SP1385.1116

Goss, A.R., Kay, S.M., 2006. Steep REE patterns and enriched Pb isotopes in southern Central American arc magmas: Evidence for forearc subduction erosion? Geochem Geophys Geosys 7, Q05016, doi:05010.01029/02005GC001163.

Goss, A.R., Kay, S.M., 2009. Extreme high field strength element (HFSE) depletion and nearchondritic $\mathrm{Nb} / \mathrm{Ta}$ ratios in Central Andean adakite-like lavas $\left(\sim 28^{\circ} \mathrm{S}, \sim 68^{\circ} \mathrm{W}\right)$. Earth Planet Sci Lett 279, 97-109.

Goss, A.R., Mahlburg Kay, S., Mpodozis, C., 2013. Andean adakite-like high-Mg andesites on the Northern margin of the Chilean-Pampean flat-slab (27-28•58S) associated with frontal arc migration and fore-arc subduction erosion. J Petrol 54, 2193-2234, doi:2110.1093/petrology/egt2044.

Hacker, B.R., Kelemen, P.B., Behn, M.D., 2011. Differentiation of the continental crust by relamination. Earth Planet Sci Lett 307 501-516, doi:510.1016/j.eps1.2011.1005.1024.

Harrison, M.T., 2009. The Hadean Crust: Evidence from >4 Ga Zircons. Annu Re. Earth Planet Sci 37,479-505, doi:410.1146/annurev.earth.031208.100151.

Hernández-Pineda, G.A., Solari, L.A., Gómez-Tuena, A., Méndez-Cárdenas, D.L., Pérez-Arvizu, O., 2011. Petrogenesis and thermobarometry of the $\sim 50$ Ma rapakivi granite-syenite Acapulco intrusive: Implications for post-Laramide magmatism in southern Mexico. Geophere 7, 1-20, doi:10.1130/GES00744.00741.

Hofmann, A.W., 2003. Sampling Mantle Heterogeneity through Oceanic Basalts: Isotopes and Trace Elements, in: Holland, H.D., Turekian, K.K., Carlson, R.W. (Eds.), Treatise on Geochemistry. Elsevier, pp. 61-101, ISBN 100-108-043751-043756.

Holm, P.M., Søager, N., Thorup Dyhr, C., Rohde Nielsen, M., 2014. Enrichments of the mantle sources beneath the Southern Volcanic Zone (Andes) by fluids and melts derived from abraded upper continental crust. Contrib Mineral Petrol 167, 1004, DOI 1010.1007/s0041000014-01004-00418.

Huene, R.v., Ranero, C.R., Vannucchi, P., 2004. Generic model of subduction erosion. Geochim Cosmochim Acta 32, 913-916, doi: 910.1130/G20563.20561.

Huene, R.v., Scholl, D.W., 1991. Observations at convergent margins concerning sediment subduction, subduction erosion, and the growth of continental crust. Reviews of Geophysics 29, 279-316. 
1005

1006

1007

1008

1009

1010

1011

1012

1013

1014

1015

1016

1017

1018

1019

1020

1021

1022

1023

1024

1025

1026

1027

1028

1029

1030

1031

1032

1033

1034

1035

1036

1037

1038

1039

1040

1041

1042

1043

1044

1045

1046

1047

1048

1049

1050

1051

1052

Jarosewich, E., Nelen, N., Norberg, J., 1980. Reference samples for electron microprobe analysis. Geostandard Newsletter 4 (1), 43-47.

Johnson, E.R., Wallace, P.J., Delgado-Granados, H., Manea, V.C., Kent, A.J.R., Bindeman, I.N., Donegan, C.S., 2009. Subduction-related volatile recycling and magma generation beneath central Mexico: insights from melt inclusions, oxygen isotopes and geodynamic models. J Petrol 50, 1729-1764, doi:1710.1093/petrology/egp1051.

Kay, R.W., 1980. Volcanic arc magmas: Implications of a melting-mixing model for element recycling in the crust-upper mantle system. Journal of Geology 88, 497-522.

Kay, S.M., Godoy, E., Kurtz, A., 2005. Episodic arc migration, crustal thickening, subduction erosion, and magmatism in the south-central Andes. Geol Soc Am Bull 117, 67-88; doi: 10.1130/B25431.25431.

Kelemen, P.B., Yogodzinksi, G., Scholl, D.W., 2003. Along-strike Variation in the Aleutian Island Arc: Genesis of high-mg\# andesite and implication for the continental crust, in: Eiler, J. (Ed.), Inside the Subduction Factory. Amer Geophys Un, pp. 223-276.

Keppie, D.F., Hynes, A.J., Lee, J.K.W., Norman, M., 2012. Oligocene-Miocene back-thrusting in southern Mexico linked to the rapid subduction erosion of a large forearc block. Tectonics 31, TC2008, doi:2010.1029/2011TC002976.

Kessel, R., Schmidt, M.W., Ulmer, P., Pettke, T., 2005. Trace element signature of subduction-zone fluids, melts and supercritical liquids at 120-180 km depth. Nature 437, 724-727, doi:710.1038/nature03971.

Kim, Y., Clayton, R.W., Jackson, J.M., 2010. Geometry and seismic properties of the subducting Cocos plate in central Mexico. J Geophys Res 115, doi:10.1029/2009JB006942, 002010.

Klimm, K., Blundy, J.D., Green, T.H., 2008. Trace element partitioning and accessory phase saturation during $\mathrm{H} 2 \mathrm{O}$-saturated melting of basalt with implications for subduction zone chemical fluxes. J Petrol 49, 523-553, doi:510.1093/petrology/egn1001.

Koenig, S., Schuth, S., 2011. Deep melting of old subducted oceanic crust recorded by superchondritic Nb/Ta in modern island arc lavas. Earth Planet Sci Lett 301, 265-274, doi:210.1016/j.epsl.2010.1011.1007.

LaGatta, A.B., 2003. Arc magma genesis in the Eastern Mexican Volcanic Belt, Department of Earth and Environmental Sciences. Columbia University, New York, p. 329.

Langmuir, C.H., Vocke, R.D.J., Hanson, G.N., Hart, S.R., 1978. A general mixing equation with applications to Icelandic basalts. Earth Planet Sci Lett 37, 380-392.

Lee, D.C., Halliday, A.N., Hein, J.R., Burton, K.W., Christensen, J.N., Guenther, D., 1999. Hafnium Isotope Stratigraphy of Ferromanganese Crusts. Science 285, 1052-1054.

Luhr, J.F., 1997. Extensional tectonics and the diverse primitive volcanic rocks in the western Mexican Volcanic Belt. Can Mineral 35, 473-500.

Manea, M., Manea, V.C., Kostoglodov, V., 2003. Sediment fill in the middle American trench inferred from gravity anomalies. Geofis Int 42, 603-612.

Manea, V.C., Manea, M., 2011. Flat-slab thermal structure and evolution beneath central Mexico. Pure Appl Geophys 168, 1475-1487, doi 1410.1007/s00024-00010-00207-00029.

Marquez, A., Oyarzun, R., Doblas, M., Verma, S.P., 1999. Alkalic (ocean-island basalt type) and calc-alkalic volcanism in the Mexican Volcanic Belt: a case for plume-related and propagating rifting in an active margin. Geochim Cosmochim Acta 27, 51-54.

Martelli, M., Nuccio, P.M., Stuart, F.M., Di Liberto, V., Ellam, R.M., 2008. Constraints on mantle source and interactions from He-Sr isotope variation in Italian Plio-Quaternary volcanism. Geochem Geophys Geosys 9, Q02001, doi:02010.01029/02007GC001730.

Martin, E., Bindeman, I., Grove, T.L., 2011. The origin of high-Mg magmas in Mt Shasta and Medicine Lake volcanoes, Cascade Arc (California): higher and lower than mantle oxygen 
1053

1054

1055

1056

1057

1058

1059

1060

1061

1062

1063

1064

1065

1066

1067

1068

1069

1070

1071

1072

1073

1074

1075

1076

1077

1078

1079

1080

1081

1082

1083

1084

1085

1086

1087

1088

1089

1090

1091

1092

1093

1094

1095

1096

1097

1098

1099 isotope signatures attributed to current and past subduction. Contrib Mineral Petrol 162, 945960, doi 910.1007/s00410-00011-00633-00414.

Martinez-Serrano, R.G., Schaaf, P., Solids-Pichardo, G., Hernandez-Bernal, M.S., HernandezTrevino, T., Morales-Contreras, J.J., Macias, J.L., 2004. Sr, Nd and Pb isotope and geochemical data from the Quaternary Nevado the Toluca volcano, a source of recent adakite magmatism, and the Tenango Volcanic Field. J Volcanol Geotherm Res 138, 77-110.

McDonough, W.F., Sun, S.S., 1995. The composition of the Earth. Chem Geol 120, 223-253.

Meriggi, L., Macías, J.L., Tommasini, S., Capra, L., Conticelli, S., 2008. Heterogeneous magmas of the Quaternary Sierra Chichinautzin volcanic field (central Mexico): the role of an amphibolebearing mantle and magmatic evolution processes. Revista Mexicana de Ciencias Geológicas 25, 197-216.

Morán-Zenteno, D.J., Corona-Chavez, P., Tolson, G., 1996. Uplift and subduction erosion in southwestern Mexico since the Oligocene: pluton geobarometry constraints. Earth Planet Sci Lett 141, 51-65, doi: 10.1016/0012-1821X(1096)00067-00062.

Mori, L., Gómez-Tuena, A., Cai, Y.M., Goldstein, S.L., 2007. Effects of prolonged flat subduction on the Miocene magmatic record of the central Trans-Mexican Volcanic Belt. Chem Geol 244 (3-4), 452-473.

Morris, J.D., Gosse, J., Brachfeld, S., Tera, F., 2002. Cosmogenic Be-10 and the Solid Earth: Studies in Geomagnetism, Subduction Zone Processes, and Active Tectonics, in: Grew, E. (Ed.), Reviews in Mineralogy. Mineralogical Society of America, Washington, DC, pp. 207-270.

Morris, J.D., Leeman, W.P., Tera, F., 1990. The subducted component in island arc lavas: constraints from Be isotopes and B-Be systematics. Nature 344, 31-36.

Muenker, C., Pfaender, J.A., Weyer, S., Buechl, A., Kleine, T., Mezger, K., 2003. Evolution of Planetary Cores and the Earth-Moon System from Nb/Ta Systematics. Science 301, 84-87.

Munker, C., Weyer, S., Scherer, E., Mezger, K., 2001. Separation of high field strength elements $(\mathrm{Nb}, \mathrm{Ta}, \mathrm{Zr}, \mathrm{Hf})$ and Lu from rock samples for MC-ICPMS measurenments. Geochem Geophys Geosys 2, doi: 10.1029/2001GC000183.

Niu, Y., Batiza, R., 1997. Trace element evidence from seamounts for recycled oceanic crust in the Eastern Pacific mantle. Earth Planet Sci Lett 148, 471-483.

Nowell, G.M., Kempton, P.D., Noble, S.R., Fitton, J.G., Saunders, A.D., Mahoney, J.J., Taylor, R.N., 1998. High precision Hf isotope measurements of MORB and OIB by thermal ionisation mass spectrometry: insights into the depleted mantle. Chem Geol 149 (3-4), 211-233.

O'Nions, R.K., Oxburgh, E.R., 1988. Helium, volatile fluxes and the development of continental crust. Earth Planet Sci Lett 90, 331-347.

Ortega-Gutiérrez, F., Elías-Herrera, M., Gómez-Tuena, A., Mori, L., Reyes-Salas, M., MacíasRomo, C., Solari, L.A., 2012. Petrology of high-grade crustal xenoliths in the Chalcatzingo Miocene subvolcanic field, southern Mexico: buried basement of the Guerrero-Morelos platform and tectonostratigraphic implications. Int Geology Review 54, 1597-1634, http://dx.doi.org/1510.1080/00206814.00202011.00649956.

Ortega-Gutiérrez, F., Gómez-Tuena, A., Elías-Herrera, M., Reyes-Salas, M., Macías-Romo, C., 2014. Petrology and geochemistry of the Valle de Santiago lower-crust xenoliths: Young tectonothermal processes beneath the central Trans-Mexican volcanic belt. Lithosphere in press, doi: 10.1130/L1317.1131.

Ortega-Gutiérrez, F., Martiny, B.M., Morán-Zenteno, D.J., Reyes-Salas, A.M., Solé-Viñas, J., 2011. Petrology of very high temperature crustal xenoliths in the Puente Negro intrusion: a sapphire-spinel-bearing Oligocene andesite, Mixteco terrane, southern Mexico. Revista Mexicana de Ciencias Geológicas 28, 593-629. 
Pardo, M., Suarez, G., 1995. Shape of the subducted Rivera and Cocos plate in southern Mexico: seismic and tectonic implications. J Geophys Res 100, 12357-12373.

Pearce, J.A., Baker, P.E., Harvey, P.K., Luff, I.W., 1995a. Geochemical evidence for subduction fluxes, mantle melting and fractional crystallization beneath the South Sandwich Island Arc. J Petrol 36, 1073-1109.

Perez-Campos, X., Kim, Y.H., Husker, A., Davis, P.M., Clayton, R.W., Iglesias, A., Pacheco, J.F., Singh, S.K., Manea, V.C., Gurnis, M., 2008. Horizontal subduction and truncation of the Cocos Plate beneath central Mexico. Geophys Res Lett 35, 18303, doi:18310.11029/12008GL035127.

Pérez-Gutiérrez, R., Solari, L.A., Gómez-Tuena, A., Martens, U., 2009. Mesozoic geologic evolution of the Xolapa migmatitic complex north of Acapulco, southern Mexico: implications for paleogeographic reconstructions. Revista Mexicana de Ciencias Geológicas 26, 201-221.

PetDB, 2011. Information System for Geochemical Data of Igneous and Metamorphic Rocks from the Ocean Floor. http://www.earthchem.org/petdb.

Pfänder, J.A., Münker, C., Stracke, A., Mezger, K., 2007. Nb/Ta and Zr/Hf in ocean island basalts Implications for crust-mantle differentiation and the fate of Niobium. Earth Planet Sci Lett 254, 158-172, doi:110.1016/j.epsl.2006.1011.1027.

Pin, C., Briot, D., Bassin, C., Poitrasson, F., 1994. Concomitant separation of strontium and samarium-neodymium for isotopic analysis in silicate samples, based on specific extraction chromatography. Analytica Chimica Acta 298, 209-217.

Plank, T., 2004. Constraints from Thorium/Lanthanum on Sediment Recycling at Subduction Zones and the Evolution of the Continents. J Petrol doi:10.1093/petrology/egi005, 1-24.

Plank, T., 2014. The Chemical Composition of Subducting Sediments, in: Holland, H., Turekian, K. (Eds.), Treatise on Geochemistry (Second Edition). Elsevier, pp. 607-629.

Plank, T., Langmuir, C.H., 1993. Tracing trace elements from sediment input to volcanic output at subduction zones. Nature 362, 739-743.

Plank, T., Langmuir, C.H., 1998. The geochemical composition of subducting sediment and its consequences for the crust and the mantle. Chem Geol 145, 325-394.

Ranero, C.R., Huene, R.v., 2000. Subduction erosion along the Middle American convergent margin. Nature 404, 748-752.

Risse, A., Trumbull, R.B., Kay, S.M., Coira, B., Romer, R.L., 2013. Multi-stage Evolution of Late Neogene Mantle-derived Magmas from the Central Andes Back-arc in the Southern Puna Plateau of Argentina. J Petrol 10, 1963-1995, doi:1910.1093/petrology/egt1038.

Roberge, J., Delgado-Granados, H., Wallace, P.J., 2009. Mafic magma recharge supplies high CO2 and $\mathrm{SO} 2$ gas fluxes from Popocatépetl volcano, Mexico. Geochim Cosmochim Acta 37, 107110; doi: 110.1130/G25242A.

Rubatto, D., Hermann, J., 2003. Zircon formation during fluid circulation in eclogites (Monviso, Western Alps):Implications for $\mathrm{Zr}$ and Hf budget in subduction zones. Geochim Cosmochim Acta 67, 2173-2187,doi:2110.1016/S0016-7037(2102)01321-01322.

Rudnick, R., 1995. Making continental crust. Nature 378, 571-578.

Rudnick, R., Gao, S., 2002. Composition of the Continental Crust, in: Rudnick, R.L. (Ed.), The Crust. Elsevier-Pergamon, Oxford, pp. 1-64.

Schaaf, P., Morales-Zenteno, D., del Sol Hernandez-Bernal, M., Solis-Pichardo, G., Tolson, G., Koehler, H., 1995. Paleogene continental margin truncation in southwestern Mexico: Geochronological evidence. Tectonics 14, 1339-1350.

Schaaf, P., Stimac, J., Siebe, C., Macias, J.L., 2005. Geochemical evidence for mantle origin and crustal processes in volcanic rocks from Popocatepetl and surrounding monogenetic volcanoes, central Mexico. J Petrol 46, 1243-1282. 
Scholl, D.W., Huene, R.v., 2009. Implications of estimated magmatic additions and recycling losses at the subduction zones of accretionary (non-collisional) and collisional (suturing) orogens, in: Cawood, P.A., Kroener, A. (Eds.), Earth Accretionary Systems in Space and Time. The Geological Society, Special Publications 2009, London, pp. 105-125, doi: 110.1144/SP1318.1144.

Siebe, C., 2000. Age and archaeological implications of Xitle volcano, southwestern Basin of Mexico City. J Volcanol Geotherm Res 104, 45-64.

Siebe, C., Rodriguez-Lara, V., Schaaf, P., Abrams, M., 2004a. Geochemistry, Sr-Nd isotope composition, and tectonic setting of Holocene Pelado, Guespalapa and Chichinautzin scoria cones, south of Mexico City. J Volcanol Geotherm Res 130, 197-226.

Siebe, C., Rodriguez-Lara, V., Schaaf, P., Abrams, M., 2004b. Radiocarbon ages of Holocene Pelado, Guespalapa, and Chichinautzin scoria cones, south of Mexico City: implications for archeology and future hazards. Bull Volcanol 66, 203-225 DOI 210.1007/s00445-00003-00304-z.

Skora, S., Blundy, J., 2010. High-pressure hydrous phase relations of radiolarian clay and implications for the involvement of subducted sediment in arc magmatism. J Petrol 51, 22112243, doi:2210.1093/petrology/egq2054.

Staudigel, H., Davies, G.R., Hart, S.R., Marchant, K.M., Smith, B.M., 1995. Large scale isotopic Sr, $\mathrm{Nd}$ and $\mathrm{O}$ isotopic anomaly of altered oceanic crust: DSDP/ODP sites 417/418. Earth Planet Sci Lett 130, 169-185.

Stern, C.R., 2011. Subduction erosion: Rates, mechanisms, and its role in arc magmatism and the evolution of the continental crust and mantle. Gondwana Res 20, 284-308, doi:210.1016/j.gr.2011.1003.1006.

Stolz, A.J., Jochum, K.P., Spettel, B., Hofmann, A.W., 1996. Fluid- and melt-related enrichment in the subarc mantle: Evidence from $\mathrm{Nb} / \mathrm{Ta}$ variations in island-arc basalts. Geochim Cosmochim Acta 24, 587-590.

Straub, S.M., Gomez-Tuena, A., Stuart, F.M., Zellmer, G.F., Cai, M.Y., Espinasa-Perena, R., 2011a. High-Ni Olivines and the Mantle Origin of Arc Andesites, XXV IUGG General Assembly, Melbourne, Australia.

Straub, S.M., Gomez-Tuena, A., Stuart, F.M., Zellmer, G.F., Espinasa-Perena, R., Cai, M.Y., Iizuka, Y., 2011b. Formation of hybrid arc andesites beneath thick continental crust. Earth Planet Sci Lett 303, 337-347, doi:310.1016/j.eps1.2011.1001.1013.

Straub, S.M., Gomez-Tuena, A., Zellmer, G.F., Espinasa-Perena, R., Stuart, F.M., Cai, Y., Langmuir, C.H., Martin-Del Pozzo, A., Mesko, G.T., 2013a. The processes of melt differentiation in arc volcanic rocks: Insights from OIB-type arc magmas in the central Mexican Volcanic Belt. J Petrol 54, , 665-701, doi:610.1093/petrology/egs1081.

Straub, S.M., Gomez-Tuena, A., Zellmer, G.F., Espinasa-Perena, R., Stuart, F.M., Cai, Y., Langmuir, C.H., Martin-Del Pozzo, A., Mesko, G.T., 2013b. The processes of melt differentiation in arc volcanic rock: Insights from OIB-type arc magmas in the central Mexican Volcanic Belt: reply to a critical comment by Claus Siebe (2013). J Petrol 54, 1551-1554, doi:1510.1093/petrology/egt1021

Straub, S.M., LaGatta, A.B., Martin-Del Pozzo, A.L., Langmuir, C.H., 2008. Evidence from high Ni olivines for a hybridized peridotite/pyroxenite source for orogenic andesites from the central Mexican Volcanic Belt. Geochem Geophys Geosys 9, Q03007, doi:03010.01029/02007GC001583. Straub, S.M., Zellmer, G.F., 2012. Volcanic Arcs as Archives of Plate Tectonic Change. Gondwana Res 21, 495-516, doi:410.1016/j.gr.2011.1010.1006

Straub, S.M., Zellmer, G.F., Gómez-Tuena, A., Espinasa-Perena, R., Martin-Del Pozzo, A.L., Stuart, F.M., Langmuir, C.H., 2014. A genetic link between silicic slab components and calc1194 alkaline arc volcanism in central Mexico in: Gomez-Tuena, A., Straub, S.M., Zellmer, G.F. 
(Eds.), Orogenic Andesites and Crustal Growth Geological Society London Special Publication, pp. 31-64, doi 10.1144/SP1385.1114.

Sun, S.S., McDonough, W.F., 1989. Chemical and isotopic systematics of oceanic basalts: implications for mantle composition and processes, in: Saunders, A.D., Norry, M.J. (Eds.), Magmatism in the Ocean Basins. Geol Soc Spec Publ Blackwell Scientific Publ, Oxford etc, pp. 313-345.

Tatsumi, Y., Eggins, E., 1995. Subduction Zone Magmatism. Blackwell Science, Cambridge MA. Taylor, S.R., 1967. The origin and growth of continents. Tectonophysics 4, 17-34.

Tera, F., Brown, L., Morris, J., Sacks, I.S., 1986. Sediment incorporation in island-arc magmas: Inferences from 10Be. Geochim Cosmochim Acta 50, 535-550.

Todt, W., Cliff, R.A., Hanser, A., Hofmann, A.W., 1996. Evaluation of a 202Pb-205Pb double-spike for high-precision lead isotope analysis:, in: Basu, A., Hart, S.R. (Eds.), Earth Processes: Reading the Isotopic Code. AGU, Washington DC, pp. 429-437.

Tonarini, S., Leeman, W.P., Leat, P.T., 2011. Subduction erosion of forearc mantle wedge implicated in the genesis of the South Sandwich Island (SSI) arc: Evidence from boron isotope systematics. Earth Planet Sci Lett 301, 275-284,doi:210.1016/j.epsl.2010.1011.1008.

Vannucchi, P., Ranero, C.R., Galeotti, S., Straub, S.M., Scholl, D.W., McDougall-Ried, K., 2003. Fast rates of subduction erosion along the Costa Rica Pacific margin: Implications for nonsteady rates of crustal recycling at subduction zones. J Geophys Res 108, 2511, 2510.1029/2002JB002207.

Verma, S.P., 1999a. Geochemistry of evolved magmas and their relationship to subductionunrelated mafic volcanism at the volcanic front of the central Mexican Volcanic Belts. J Volcanol Geotherm Res 93, 151-171.

Verma, S.P., 1999b. Geochemistry of the subducting Cocos plate and the origin of subductionunrelated mafic volcanism at the volcanic front of the central Mexican Volcanic Belt, in: Delgado-Granados, H., Aguirre-Diaz, G., Stock, J.M. (Eds.), Cenozoic Tectonics and Volcanism at the volcanic front of the central Mexican Volcanic Belt, pp. 1-28.

Vervoort, J.D., Plank, T., Prytulak, J., 2011. The Hf-Nd isotopic composition of marine sediments. Geochimica et Cosmochimica Acta 75, 5903-5926, doi:5910.1016/j.gca.2011.5907.5046.

Wallace, P.J., Carmichael, I.S.E., 1999. Quaternary volcanism near the Valley of Mexico: implications for subduction zone magmatism and the effects of crustal thickness variations on primitive magma compositions. Contrib Mineral Petrol 135, 291-314.

Watkins, J.S., McMillen, K.J., Bachman, S.B., Shipley, T.H., Moore, J.C., Angevine, C., 1981. Tectonic synthesis Leg 66: Transect and vicinity, in: Watkins, J.S., Moore, J.C. (Eds.), DSDP Leg 66 Report. US Gov Printing Office, Washington, pp. 837-849.

Watkins, J.S., Moore, J.C., 1981. Introduction: Scientific objectives and explanatory notes, Initial Reports DSDP 66. US Govt Printing Office, Washington. 


\section{FIGURE CAPTIONS}

1234 Figure 1: Plate tectonic setting of the Trans-Mexican Volcanic Belt (MVB). a. Locations of 1235 DSDP/ODP/IODP drill sites samples on Pacific Plate (MORB glasses) and Cocos Plate (sediment, continental basement), and crust outcrops and xenoliths within and south of the MVB. Numbers in brackets next to IODP drill sites are basement ages in million years. Piston corer locations from Cai et al. (2014). Basemap from GeoMappApp (2014). b. Trans-Mexican Volcanic Belt (grey shaded) with principal Quaternary volcanoes redrawn from Blatter et al. (2001). Slab contours after Pardo and Suarez (1995). Locations of crustal materials are those of Gómez-Tuena et al. (2003, Palma Sola xenoliths), Martinez-Serrano et al. (2004,Nevado de Toluca xenoliths), Schaaf et al. (2005, Popocatepetl xenoliths), Gómez-Tuena et al. (2008, Chalcatzingo xenolith), OrtegaGutiérrez et al. (2011, Puente Negro xenoliths), Hernández-Pineda et al. (2011, Eocene Acapulco intrusion ), Pérez-Gutiérrez et al. (2009, Mesozoic Xolapa migmatites) and Ortega-Gutiérrez et al. (2014, Valle Santiago xenoliths ). NDT - Nevado de Toluca, POP - Popocatepetl EPR - East Pacific Rise, RFZ - Rivera Fracture Zone, MC - Mexico City, TFZ - Tamayo Fracture Zone. c. NESW cross section of Mexican continental slope and trench with incoming Cocos plate drilled during DSDP Leg 66, redrawn from Watkins et al. (1981). Continental basement was drilled at Sites 493 (granodiorite) and 489 (B -biotite gneiss). Trench sediment was analyzed at Sites 488 and 487 (Cai et al., 2014; LaGatta, 2003; Plank, 2014; Plank and Langmuir, 1998; Verma, 1999b), and circles) of the Sierra Chichinautzin Volcanic Field are flanked by Quaternary composite volcanoes Nevado de Toluca and Popocatepetl-Iztaccihuatl. Large symbols denote samples with olivines analyzed for both ${ }^{3} \mathrm{He} /{ }^{4} \mathrm{He}$ and $\delta^{18} \mathrm{O}$. Location of most mantle-like magmas ('Old Texcal Flow') is indicated, as well as location of high-La volcanic rocks (St. Cruz, Tuxtepec and Yecahuazac Cone). CV - City of Cuernavaca, TL City of Toluca

Figure 3: Multi-element diagram of incompatible trace elements of central MVB magmas normalized to primitive mantle of McDonough and Sun (1995). For clarity, only magmas with high ${ }^{3} \mathrm{He} /{ }^{4} \mathrm{He}$ and high $\delta^{18} \mathrm{O}$ are shown. a. Thick black line denotes the 'Old Texcal Flow' which is least influenced by slab and closely resembles a $\sim 3.5 \%$ melt from primitive mantle (Straub et al., 2013a, 2013b). While per definition a high- $\mathrm{Nb}$ basalt $(\mathrm{Nb}=18 \mathrm{ppm})$, it has no end member character and is intermediate to calc-alkaline and high-Nb series. b. MVB magmas compared to melts from residual mantle after 3.5 to $10 \%$ melt extraction from a primitive mantle (which produced the Old Texcal Flow after minor subduction modification). Residual mantle modeled from primitive mantle McDonough and Sun (1995) and partition coefficients from Donnelly et al. (2004). Mantle depletion by melting is so efficient that the slab flux either strongly influences (MREE) or controls (LREE and more incompatible elements) the arc budgets of elements more incompatible than Ho. Only $\mathrm{Ti}$ and rare earth elements Ho to Lu remain mantle- controlled by mantle. See also Straub et al. (2014). 
Figure 4: ${ }^{3} \mathrm{He} /{ }^{4} \mathrm{He}$ vs $\delta^{18} \mathrm{O}$ of olivine phenocrysts in central MVB volcanic rocks. $\delta^{18} \mathrm{O}$ recalculated to ratios in equilibrium melt $\left[\delta^{18} \mathrm{O}_{\text {melt }}=\delta^{18} \mathrm{O}_{\text {oliv }}+0.088^{*} \mathrm{SiO}_{2}-3.57\right.$ after Bindeman (2008)]. ${ }^{3 \mathrm{He}} /{ }^{4} \mathrm{He}$ of olivines are from Straub et al. (2011b). ${ }^{3} \mathrm{He} /{ }^{4} \mathrm{He}$ in MORB and continental crust from Farley et al. (1998) and O'Nions and Oxburgh (1988); $\delta^{18} \mathrm{O}$ in mantle rocks from Bindeman (2008). Host magmas are basalts to andesites with up to $61 \mathrm{wt} \% \mathrm{SiO}_{2}$.

Figure 5: ${ }^{87} \mathrm{Sr} /{ }^{86} \mathrm{Sr}$ vs ${ }^{143} \mathrm{Nd} /{ }^{144} \mathrm{Nd}$ of volcanic rocks and various crustal materials (Cenozoic MORB, trench sediment, continental basement). See Figure 1 for sample locations. Quaternary MORB is from the East Pacific Rise (PetDB, 2011). Large symbols denote volcanic rocks with olivines analyzed for ${ }^{3} \mathrm{He} /{ }^{4} \mathrm{He}$ and $\delta^{18} \mathrm{O}$. Thick grey lines are simple mixing curves between $\mathrm{AOC}$, mantle wedge (which have similar ${ }^{87} \mathrm{Sr} /{ }^{86} \mathrm{Sr}$ and $\mathrm{Sr} / \mathrm{Nd}$ ) and trench sediment (see text for discussion). The biotite gneiss of DSDP Site 489 it marked with a 'B'. Inset identifies the Old Texcal Flow and illustrates differences between calc-alkaline, high-La and $\mathrm{Nb}$-rich magmas. For data sources see text. crustal materials (MORB, trench sediment, continental basement). See Figure 5 for symbols. Thick grey lines are simple mixing curves between $\mathrm{AOC}$ and trench sediment. Note that a mantle component would not affect the curvature of the mixing line, since mantle has similar $\mathrm{Nd} / \mathrm{Hf} \sim 4$ (as well as $\mathrm{Nd}$ and $\mathrm{Hf}$ isotopic ratios) as the AOC. Mixing models must match arc data in both diagrams to be valid. The trench sediment fails as crust end member, while the offshore/Acapulco granodiorite lie in line with the AOC and compositions. Inset identifies the Old Texcal Flow and illustrates differences between calc-alkaline, high-La and Nb-rich magmas. For data sources see text. and crustal materials (MORB, trench sediment, continental basement). See Figure 5 for symbols. The thick grey line is a mixing curve (which are linear in $\mathrm{Pb}$ isotope space) through the central MVB magmas which are aligned with slab and mantle materials. The Cenozoic AOC (average 18.2) fits much better as unradiogenic end member of the arc array than the more variable zeroage Quaternary MORB from the East Pacific Rise. Inset identifies the Old Texcal Flow and illustrates differences between calc-alkaline, high-La and $\mathrm{Nb}$-rich magmas. For data sources see text. $\mathrm{SiO}_{2} \mathrm{wt} \%$ (bulk rock) with mixing curves from Straub et al. (2014). c. $\delta^{18} \mathrm{O}$ (olivine) vs $\mathrm{SiO}_{2} \mathrm{wt} \%$ (bulk rock), and d. $\delta^{18} \mathrm{O}_{\text {melt }}$ [calculated from olivine after Bindeman (2008): $\delta^{18} \mathrm{O}_{\text {melt }}=\delta^{18} \mathrm{O}_{\text {oliv }}+0.088$ 1315 discussion. 

from Straub et al. (2011b; 2013a, this study; 2008). The $\delta^{18} \mathrm{O}$ of continental crust is after Bindeman (2008).

Figure 10: Nd-Hf isotope and trace element mixing models. Valid models require mixing curves to pass through arc data in both the ${ }^{143} \mathrm{Nd} /{ }^{143} \mathrm{Nd} v s{ }^{176} \mathrm{Hf} /{ }^{177} \mathrm{Hf}$ and $\mathrm{Nd} / \mathrm{Hf} v s{ }^{176} \mathrm{Hf} /{ }^{177} \mathrm{Hf}$ space. The models first calculate a 'bulk slab component' (AOC and bulk trench sediment, or AOC and granodiorite) shown as thick lines with $10 \%$ increments. The bulk slab component then mixes with the mantle wedge, shown as lines with only two tick marks (1\% and $10 \%)$ for clarity (dashed - denotes curve for Nb-rich magmas). for . a.-b. Mixing between AOC and bulk trench sediment with preferential release of $\mathrm{Hf}$ from sediment by a factor of 7. c.-d. Mixing between AOC and bulk trench sediment with preferential release of $\mathrm{Nd}$ from $\mathrm{AOC}$ by a factor of 7 . Either model produces misfits in the $\mathrm{Nd} / \mathrm{Hf} v s{ }^{176} \mathrm{Hf} / 177 \mathrm{Hf}$ space (except for the high-La basalts). e.-f. Mixing between $\mathrm{AOC}$ and granodiorite that have similar $\mathrm{Nd} / \mathrm{Hf}$ ratios. Calc-alkaline and $\mathrm{Nb}$-rich magmas require slightly different crustal and mantle end members in isotope space. Mixing model assumes primitive background mantle $(\mathrm{Nd} / \mathrm{Hf}=4.4)$ for $\mathrm{Nb}$-rich magmas, and a residual mantle after by $5 \%$ melt extraction for calc-alkaline series $(\mathrm{Nd} / \mathrm{Hf}=3.9)$. For details see text.

Figure 11: Idealized ${ }^{87} \mathrm{Sr} /{ }^{86} \mathrm{Sr} v{ }^{143} \mathrm{Nd} /{ }^{144} \mathrm{Nd}$ mixing model for calc-alkaline/high-La and $\mathrm{Nb}$-rich magmas, respectively, with AOC, granodiorite and mantle wedge as end members. The models first calculate a 'bulk slab component'(AOC and bulk trench sediment, or AOC and granodiorite) which are shown as thick lines with $10 \%$ increments. The bulk slab component then mixes with the mantle wedge, shown as lines with only two tick marks $(1 \%$ and $10 \%)$ for clarity (dashed denotes curve for $\mathrm{Nb}$-rich magmas). A successful model for the calc-alkaline series requires a component with increased ${ }^{87} \mathrm{Sr} /{ }^{86} \mathrm{Sr}$, depicted here to derive from subducted AOC.

Figure 12: Idealized ${ }^{208} \mathrm{~Pb} /{ }^{204} \mathrm{~Pb}$ vs. ${ }^{206} \mathrm{~Pb} /{ }^{204} \mathrm{~Pb}$ mixing model for a. calc-alkaline/high-La magmas, and $\mathrm{b}$. Nb-rich magmas. The models first calculate a 'bulk slab component'(AOC and bulk trench sediment, or AOC and granodiorite) which are shown as thick lines with $10 \%$ increments (dashed - denotes curve for Nb-rich magmas in panel b). The bulk slab component then mixes with the mantle wedge, shown as lines with only two tick marks (1\% and 10\%) for clarity (dashed denotes curve for $\mathrm{Nb}$-rich magmas).

1354

Figure 13: a. Percentage of slab-derived $\mathrm{Pb}$ in arc magmas vs. ${ }^{206} \mathrm{~Pb} / 208 \mathrm{~Pb}$. b. Percentage of slabderived $\mathrm{Sr}$ in arc magmas vs. ${ }^{87} \mathrm{Sr} /{ }^{86} \mathrm{Sr}$. For calculation of slab-derived percentages see text. $\mathrm{c}$. Percentage of slab-derived $\mathrm{Nd}$ in arc magmas vs. ${ }^{143} \mathrm{Nd} /{ }^{143} \mathrm{Nd}$. d. Percentage of slab-derived $\mathrm{Hf}$ in arc magmas vs. ${ }^{176} \mathrm{Hf} / 177 \mathrm{Hf}$.

Figure 14: Cartoon of central MVB subduction setting. Thermal structure model assumes mantle potential temperature of $1450^{\circ} \mathrm{C}$ and temperatures of $\sim 700-800^{\circ} \mathrm{C}$ at about $110 \mathrm{~km}$ beneath the central MVB arc front, estimated from P-wave seismic tomography (Manea and Manea, 2011). 
1358 Slab surface temperatures remains below sediment solidus $\left(\geq 1050^{\circ} \mathrm{C}\right.$, Behn et al., 2011)), but are

1359 conducive to the formation of thermochemical instabilities at the slab-mantle interface.

1360

1361 Figure 15: a.-b. Th/La vs. ${ }^{143} \mathrm{Nd} /{ }^{144} \mathrm{Nd}$, and c.-d. $\mathrm{Nb} / \mathrm{Ta}$ vs. ${ }^{143} \mathrm{Nd} /{ }^{144} \mathrm{Nd}$ and mixing models for

1362 MVB magmas and their source components. Stippled lines outlines the range of the

1363 Acapulco/offshore granodiorites. The mixing models first calculate a 'bulk slab component' from

1364 AOC and eroded crust (thick lines with $10 \%$ increments). The bulk slab component then mixes

1365 with the mantle wedge, shown as lines with only two tick marks (1\% and $10 \%$ ) for clarity (dashed

1366 - denotes curve for Nb-rich magmas). Averages of major Earth reservoirs (right panels) are

1367 compiled from Plank (2004), McDonough and Sun (1995), Sun and McDonough (1989), Pfänder et

1368 al. (2007), and Muenker et al. (2003).

1369

1370 Figure 16: $\mathrm{Nb}$ (ppm) vs $\mathrm{Nb}$ /Ta of central MVB arc volcanic rocks with range of MORB from Niu

1371 and Batiza (1997). Stippled lines mark average of Old Texcal Flow (proxy to subarc mantle wedge

1372 prior to subduction modification).

1373

1374 
Table 1: Average percentages of slab contributions of $\mathrm{Pb}, \mathrm{Sr}, \mathrm{Nd}$ and $\mathrm{Hf}$ to calc-alkaline, high$\mathrm{La}$ and $\mathrm{Nb}$-rich magmas from trace element inversion.

\begin{tabular}{|c|c|c|c|c|}
\hline & $\mathbf{S r}$ & $\mathbf{P b}$ & $\mathbf{N d}$ & Hf \\
\hline calc-alkaline magmas & $87 \pm 4 \%$ & $89 \pm 6 \%$ & $74 \pm 8 \%$ & $69 \pm 9 \%$ \\
\hline from mantle & $\sim 13 \%$ & $\sim 11 \%$ & $\sim 26 \%$ & $\sim 31 \%$ \\
\hline & & & & \\
\hline high-La series magmas & $95 \pm 2 \%$ & $96 \pm 2 \%$ & $93 \pm 3 \%$ & $73 \pm 7 \%$ \\
\hline from mantle & $\sim 5 \%$ & $\sim 4 \%$ & $\sim 7 \%$ & $\sim 27 \%$ \\
\hline & & & & \\
\hline Nb-rich magmas & $49 \pm 10 \%$ & $59 \pm 18 \%$ & $47 \pm 16 \%$ & $44 \pm 13 \%$ \\
\hline from mantle & $\sim 51 \%$ & $-41 \%$ & $-53 \%$ & $-56 \%$ \\
\hline
\end{tabular}


Table 2: Source components used for ${ }^{143} \mathrm{Nd} /{ }^{143} \mathrm{Nd} v s .{ }^{176} \mathrm{Hf} /{ }^{177} \mathrm{Hf}$ isotope mixing models.

\begin{tabular}{|c|c|c|c|c|c|c|c|c|c|c|c|c|}
\hline & ${ }^{87} \mathrm{Sr} /{ }^{86} \mathrm{Sr}$ & ${ }^{143} \mathrm{Nd} /{ }^{144} \mathrm{Nd}$ & ${ }^{206} \mathrm{~Pb} /{ }^{208} \mathrm{~Pb}$ & ${ }^{208} \mathbf{P b} /{ }^{208} \mathbf{P b}$ & ${ }^{176} \mathbf{H f} /{ }^{177} \mathbf{H f}$ & $\begin{array}{l}\mathrm{Pb} \\
\mathrm{ppm}\end{array}$ & $\begin{array}{c}\mathrm{Sr} \\
\mathrm{ppm}\end{array}$ & $\begin{array}{l}\text { Nd } \\
\text { ppm }\end{array}$ & $\begin{array}{c}\text { Hf } \\
\text { ppm }\end{array}$ & $\mathrm{Sr} / \mathrm{Nd}$ & $\mathrm{Nd} / \mathrm{Hf}$ & Data Sources \\
\hline $\begin{array}{l}\text { Cenozoic MORB } \\
(\mathrm{AOC})\end{array}$ & 0.70350 & 0.51319 & 18.20 & 37.71 & 0.28321 & 0.62 & $123^{a}$ & 10.28 & 2.57 & 11.9 & 4.00 & this study \\
\hline $\begin{array}{l}\text { Bulk trench } \\
\text { sediment }\end{array}$ & 0.70825 & 0.51253 & 18.64 & 38.34 & 0.28290 & 38.9 & 208 & 28.5 & 2.48 & 7.3 & 11.5 & (Cai et al., 2014; Plank, 2014) \\
\hline $\begin{array}{l}\text { Pelagic trench } \\
\text { sediment }\end{array}$ & 0.70837 & 0.51253 & 18.51 & 38.19 & 0.28294 & 66.2 & 284 & 51.2 & 2.51 & 5.6 & 20.4 & $\begin{array}{l}\text { (Cai et al., 2014; LaGatta, 2003; } \\
\text { Verma, 1999b) }\end{array}$ \\
\hline $\begin{array}{l}\text { Terrigenous trench } \\
\text { sediment }\end{array}$ & 0.70858 & 0.51248 & 18.84 & 38.62 & 0.28278 & 20.9 & 179 & 19.8 & 2.43 & 9.1 & 8.15 & $\begin{array}{l}\text { (Cai et al., 2014; LaGatta, 2003; } \\
\text { Verma, 1999b) }\end{array}$ \\
\hline \multicolumn{13}{|l|}{$\begin{array}{l}\text { calk-alkaline/high-La } \\
\text { series }\end{array}$} \\
\hline $\begin{array}{l}\text { Background mantle } \\
\text { wedge }\end{array}$ & 0.70307 & 0.51300 & 18.71 & 38.41 & 0.28306 & 0.076 & 7.8 & 0.63 & 0.164 & 12.3 & 3.86 & $\begin{array}{l}\text { this study; residual of primitive } \\
\text { mantle from McDonough and } \\
\text { Sun (1995), after 3.5\% melt } \\
\text { extraction }\end{array}$ \\
\hline $\begin{array}{l}\text { Acapulco/offshore } \\
\text { granodiorite }\end{array}$ & 0.70460 & 0.51273 & 18.8 & 38.64 & 0.28291 & 13.6 & $294^{\mathrm{b}}$ & 32.8 & 5.70 & 9.0 & 5.75 & this study. \\
\hline \multicolumn{13}{|l|}{$N b$-rich series } \\
\hline $\begin{array}{l}\text { Background mantle } \\
\text { wedge }\end{array}$ & 0.70307 & 0.51300 & 18.71 & 38.41 & 0.28306 & 0.15 & 19.9 & 1.25 & 0.283 & 15.9 & 4.42 & $\begin{array}{l}\text { this study; primitive mantle } \\
\text { from McDonough and Sun } \\
\text { (1995) }\end{array}$ \\
\hline intraplate seamount & $0.70460^{c}$ & $0.51273^{c}$ & $18.8^{\mathrm{c}}$ & $38.64^{c}$ & $0.2829^{c}$ & 1.2 & 270 & 21.2 & 4.2 & 12.8 & 5.0 & $\begin{array}{l}\text { abundance data after Niu and } \\
\text { Batiza (1997), Nb>10 ppm }\end{array}$ \\
\hline
\end{tabular}

a Model in Figure 14, uses increased Sr abundances, by factor of 3 for calc-alkaline series ( $\mathrm{Sr}=368 \mathrm{ppm}$; $\mathrm{Sr} / \mathrm{Nd}=36)$, and by a factor of $2.5 \mathrm{for}$ the $\mathrm{NEAB}(\mathrm{Sr}=306 \mathrm{ppm}$; $\mathrm{Sr} / \mathrm{Nd}=30$ ).

b Model in Figure 14, uses increased Sr abundances, by factor of 4 ( $\mathrm{Sr}=1177 \mathrm{ppm} ; \mathrm{Sr} / \mathrm{Nd}=36)$

c Isotope ratios estimated from trend of $\mathrm{Nb}$-rich magmas in $\mathrm{Sr}-\mathrm{Nd}-\mathrm{Pb}-\mathrm{Hf}$ isotope space 
Table 3. Average percentages of $\mathrm{Pb}, \mathrm{Sr}, \mathrm{Nd}$ and $\mathrm{Hf}$ contributed from the mantle and the different slab reservoirs obtained from isotope modeling.

\begin{tabular}{|r|c|c|c|c|}
\hline & $\mathbf{S r} \%$ & $\mathbf{P b} \%$ & $\mathbf{N d} \%$ & $\mathbf{H f} \%$ \\
\hline Calc-alkaline/high-La series & & & & \\
\hline mantle & 4 & 14 & 11 & 14 \\
\hline AOC & 23 & 25 & 21 & 27 \\
\hline Granodiorite & 73 & 61 & 68 & 59 \\
\hline Nb-rich magmas & & & & \\
\hline & & & & \\
\hline mantle & 22 & 24 & 24 & 25 \\
\hline AOC & 42 & 22 & 25 & 28 \\
\hline Seamount & 37 & 54 & 51 & 46 \\
\hline
\end{tabular}


Table 4: Source components used for Th/La vs. ${ }^{143} \mathrm{Nd} /{ }^{143} \mathrm{Nd}$ and $\mathrm{Nb} / \mathrm{Ta}$ vs. ${ }^{143} \mathrm{Nd} /{ }^{143} \mathrm{Nd}$ mixing models.

\begin{tabular}{|c|c|c|c|c|c|c|c|c|}
\hline & ${ }^{143} \mathrm{Nd} /{ }^{144} \mathrm{Nd}$ & Th ppm & La ppm & $\mathrm{Nb}$ ppm & Ta ppm & $\mathrm{Th} / \mathrm{La}$ & $\mathrm{Nb} / \mathrm{Ta}$ & Data Sources \\
\hline $\begin{array}{l}\text { Cenozoic MORB } \\
\text { (AOC) }\end{array}$ & 0.51319 & 0.33 & 4.9 & 4.55 & 0.285 & 0.07 & 15.6 & this study \\
\hline $\begin{array}{l}\text { Bulk trench } \\
\text { sediment }\end{array}$ & 0.51253 & 6.00 & 36.3 & 8.65 & 0.557 & 0.17 & 15.5 & (Cai et al., 2014; Plank, 2014) \\
\hline $\begin{array}{l}\text { Pelagic trench } \\
\text { sediment }\end{array}$ & 0.51253 & 5.51 & 56.4 & 8.09 & 0.44 & 0.08 & 18.2 & $\begin{array}{l}\text { (Cai et al., 2014; LaGatta, 2003; Verma, } \\
\text { 1999b) }\end{array}$ \\
\hline $\begin{array}{l}\text { Terrigenous trench } \\
\text { sediment }\end{array}$ & 0.51248 & 7.50 & 20.4 & 11.04 & 0.84 & 0.32 & 13.2 & $\begin{array}{l}\text { (Cai et al., 2014; LaGatta, 2003; Verma, } \\
\text { 1999b) }\end{array}$ \\
\hline $\begin{array}{l}\text { Acapulco/offshore } \\
\text { granodiorite }\end{array}$ & $0.51270-0.51276$ & $1.1-13.6$ & $15.1-37.1$ & $15.7-30.9$ & $\begin{array}{c}1.36- \\
1.58 \\
\end{array}$ & $\begin{array}{l}0.07- \\
0.37\end{array}$ & $\begin{array}{l}11.5- \\
19.6\end{array}$ & this study. \\
\hline \multicolumn{9}{|l|}{$\begin{array}{l}\text { calk-alkaline/high-La } \\
\text { series }\end{array}$} \\
\hline $\begin{array}{l}\text { Background mantle } \\
\text { wedge }\end{array}$ & 0.51300 & 0.0011 & 0.105 & 0.02 & 0.0012 & 0.01 & 16.22 & $\begin{array}{l}\text { this study; residual of primitive mantle } \\
\text { from McDonough and Sun (1995), after } \\
3.5 \% \text { melt extraction }\end{array}$ \\
\hline \multicolumn{9}{|l|}{$\mathrm{Nb}$-rich magmas } \\
\hline $\begin{array}{l}\text { Background mantle } \\
\text { wedge }\end{array}$ & 0.51300 & 0.0795 & 0.648 & 0.6 & 0.037 & 0.12 & 16.22 & $\begin{array}{l}\text { this study; primitive mantle from } \\
\text { McDonough and Sun (1995) }\end{array}$ \\
\hline
\end{tabular}




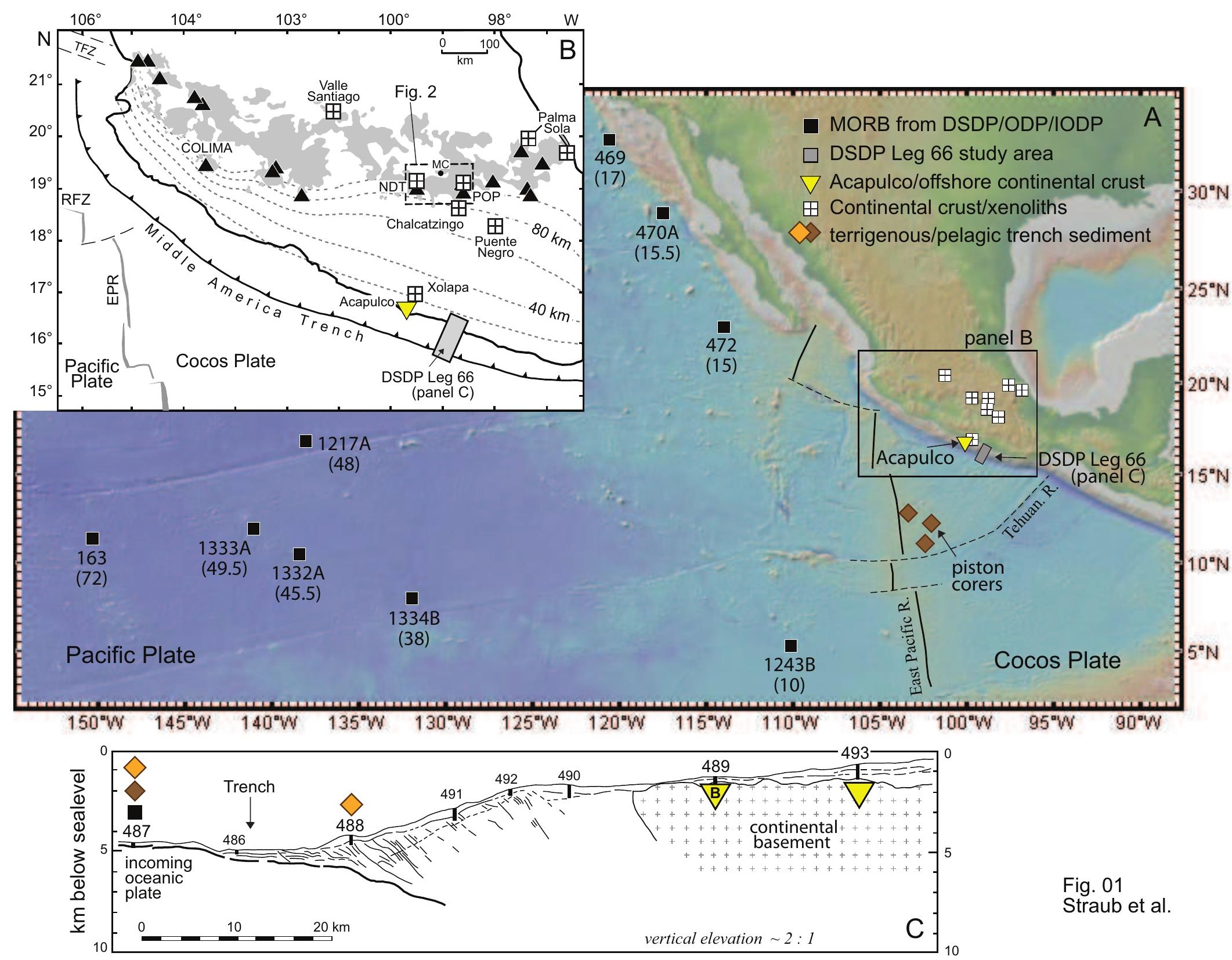


Figure $_{1}$

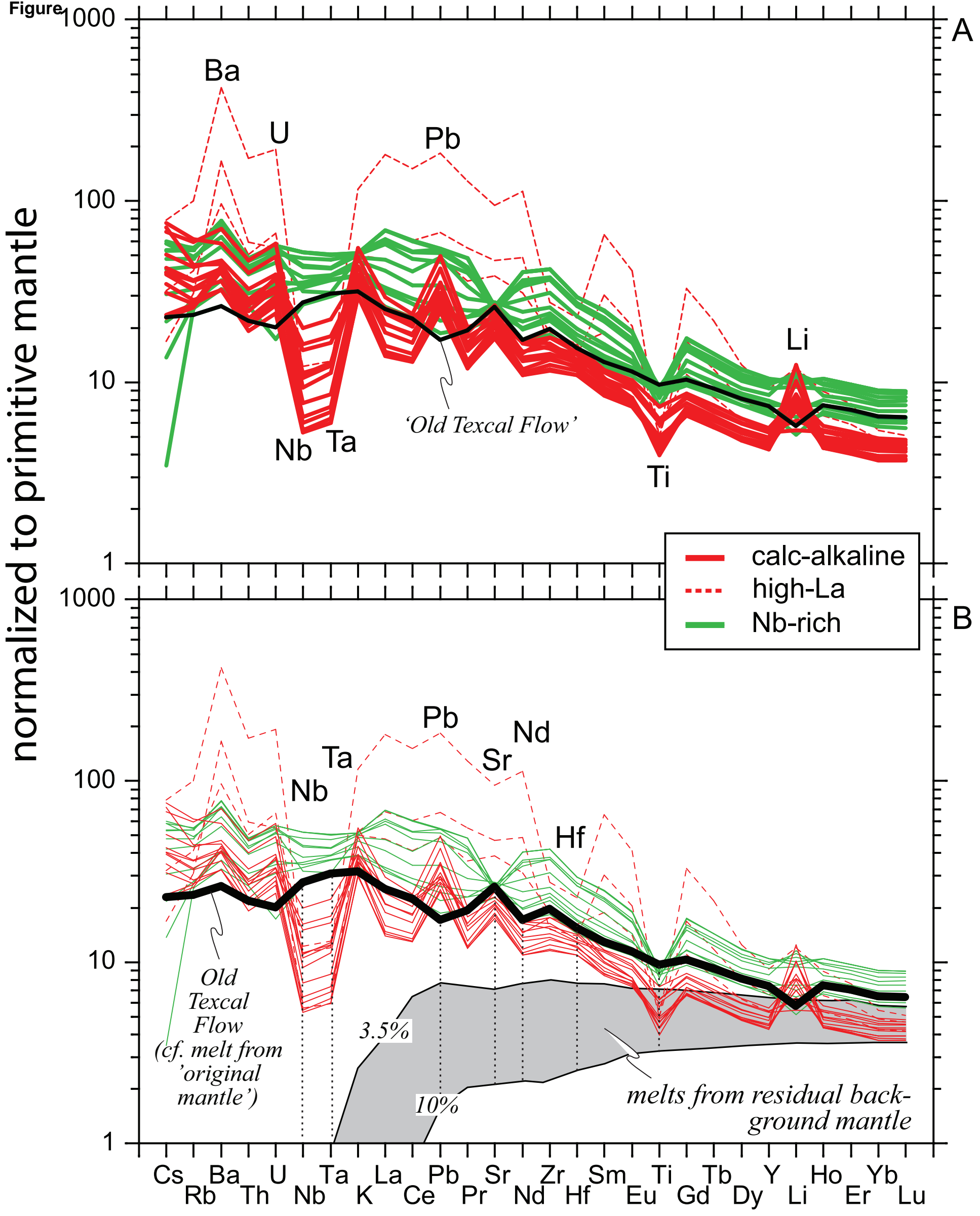

Fig. 03

Straub et al. 
Figure

10

$\frac{\Phi}{2}$

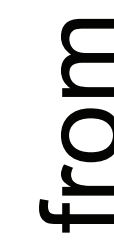

I

$\frac{\mathscr{1}}{\frac{1}{ \pm}} \frac{1}{\frac{1}{m}}$

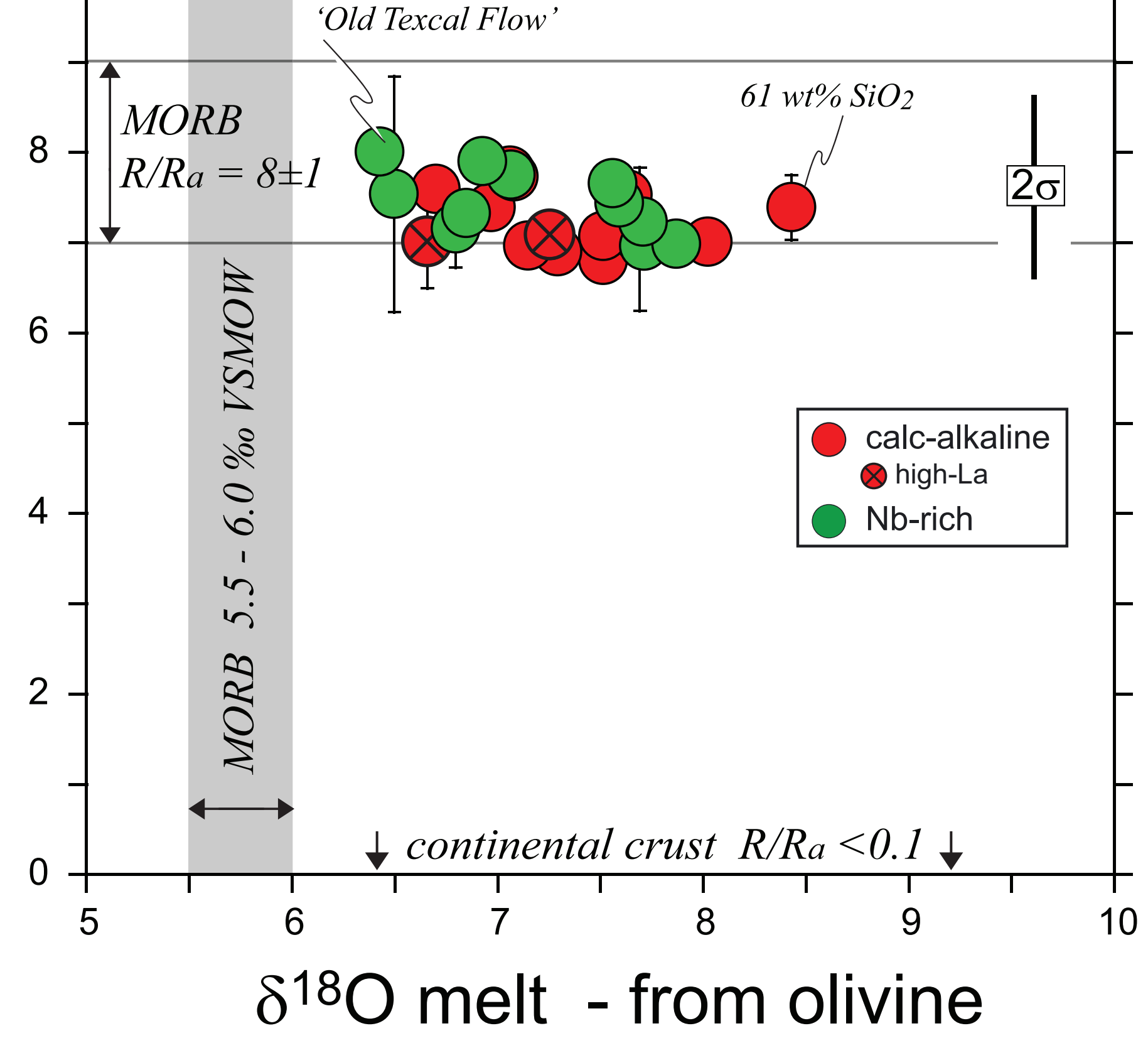

Fig. 04

Straub et al. 


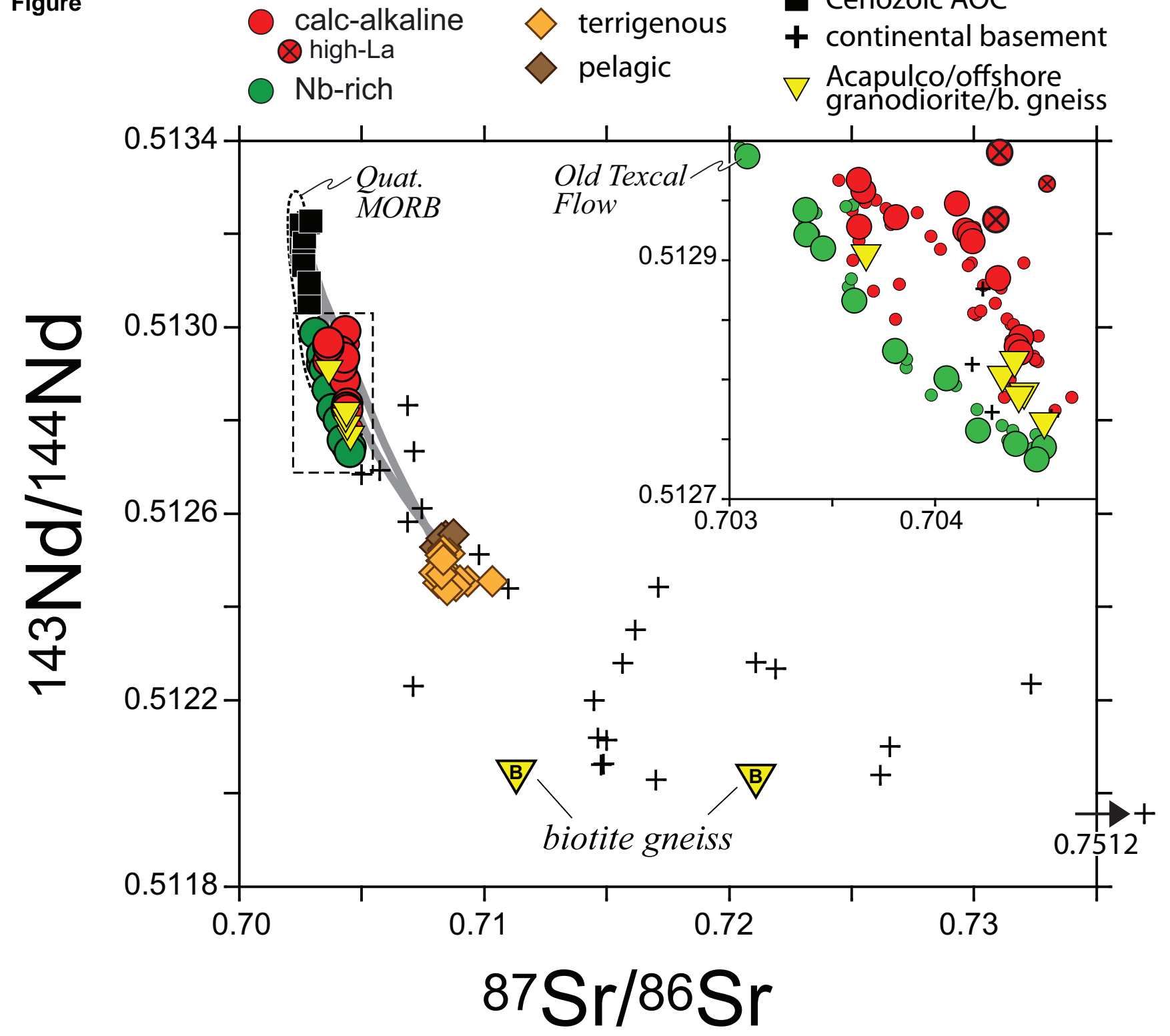

Fig. 05

Straub et al. 


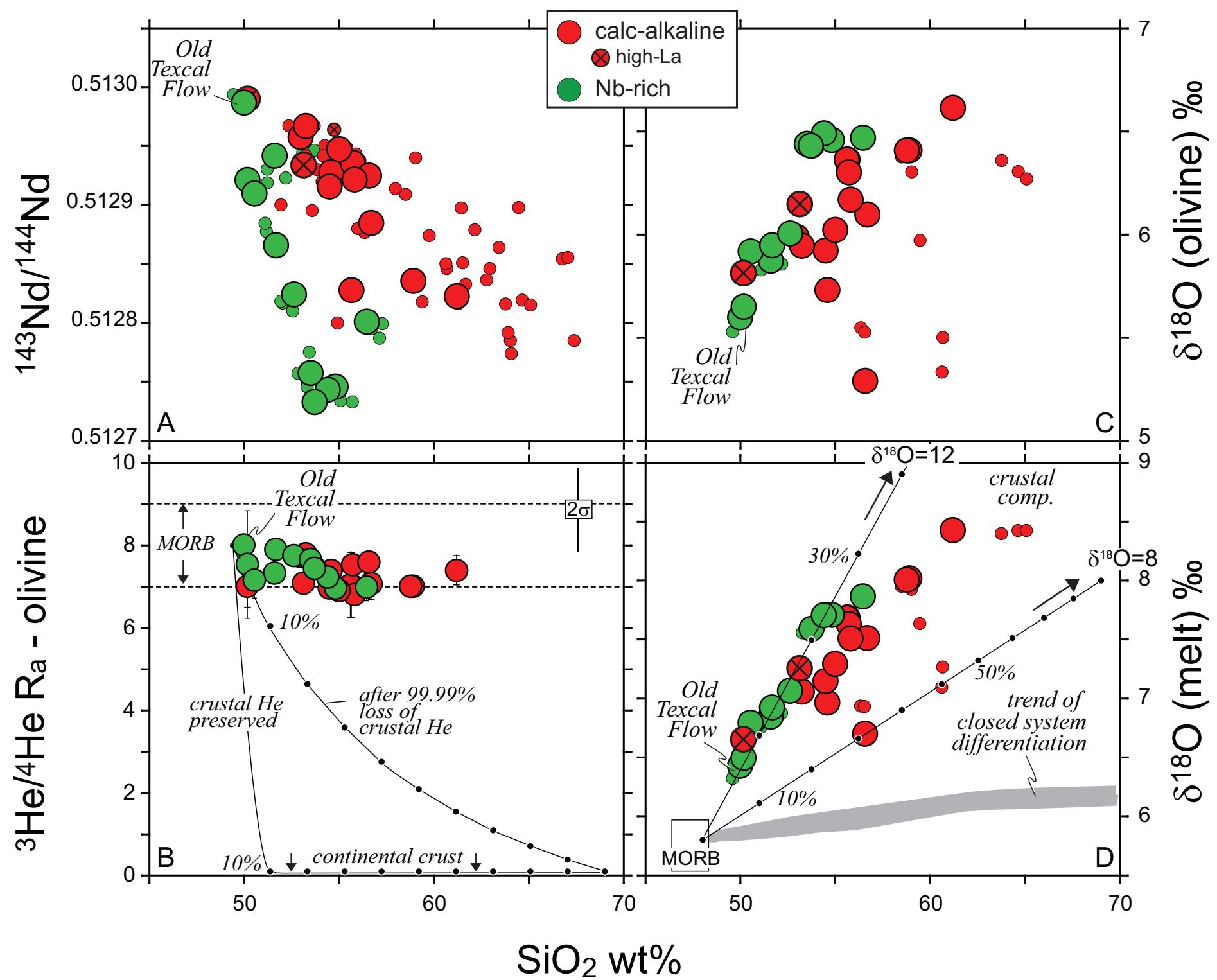

Fig. 08

Straub et al. 
Figure

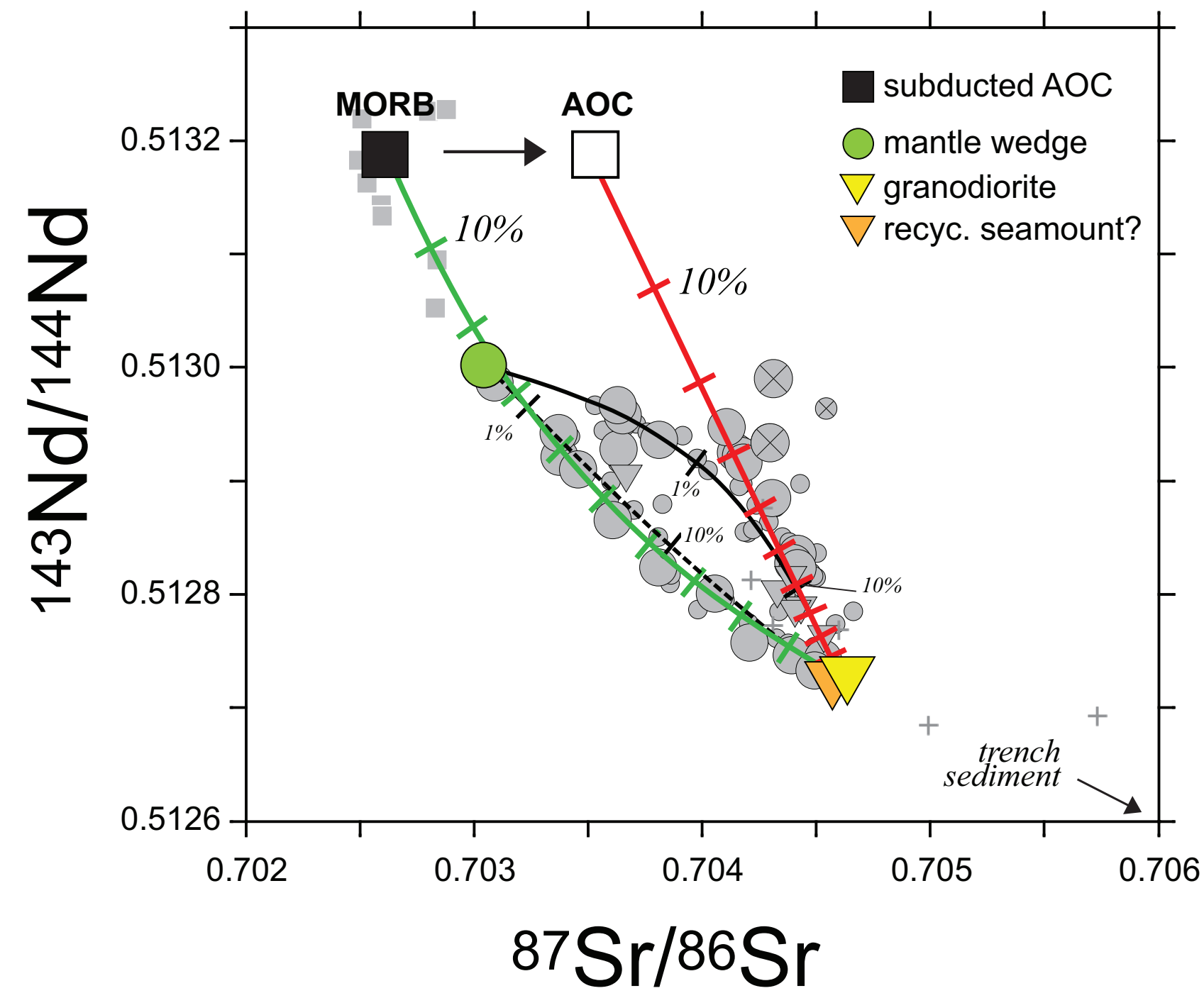

Fig. 11

Straub et al. 


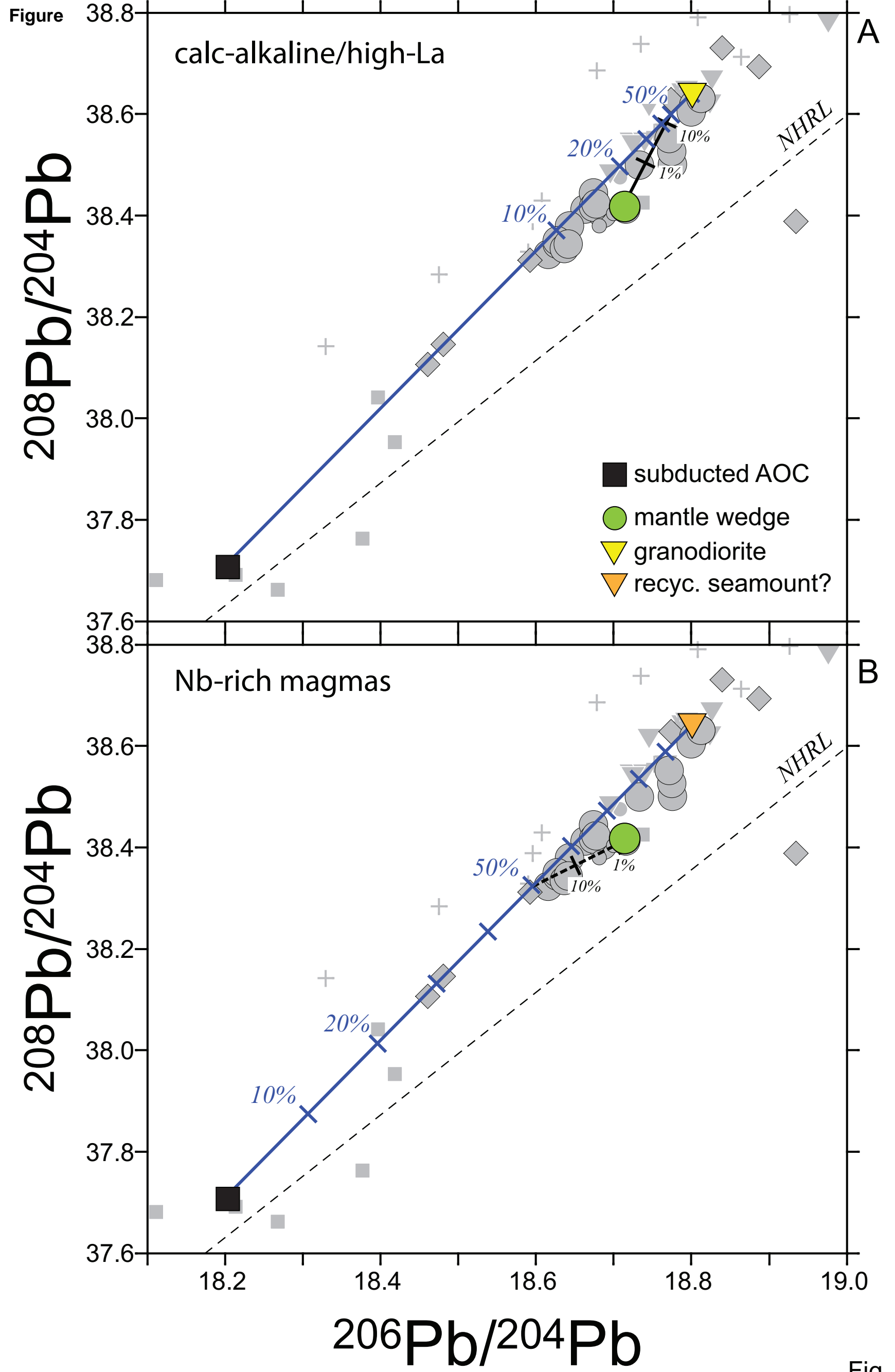

Fig. 12

Straub et al. 


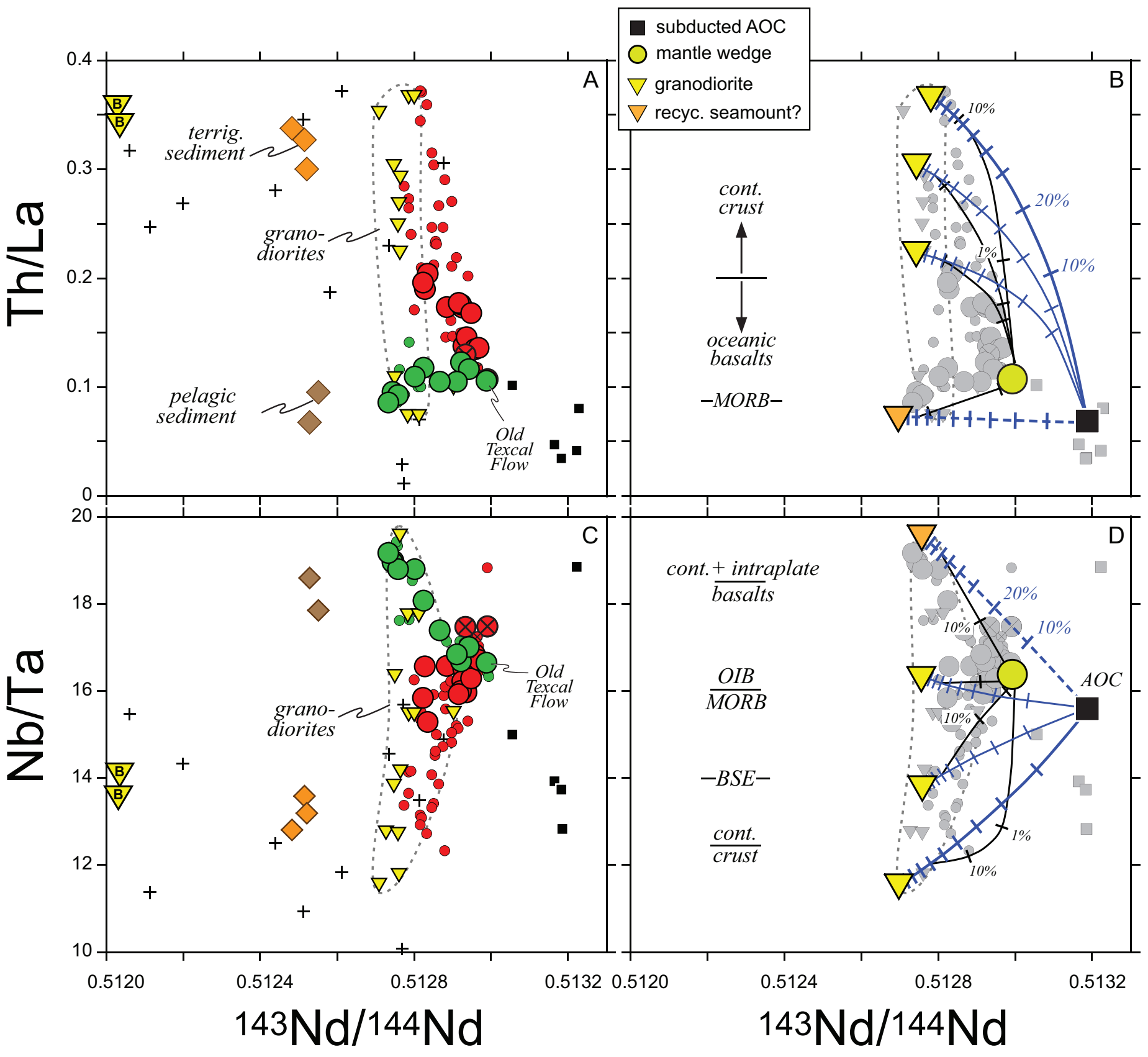

Fig. 15

Straub et al. 


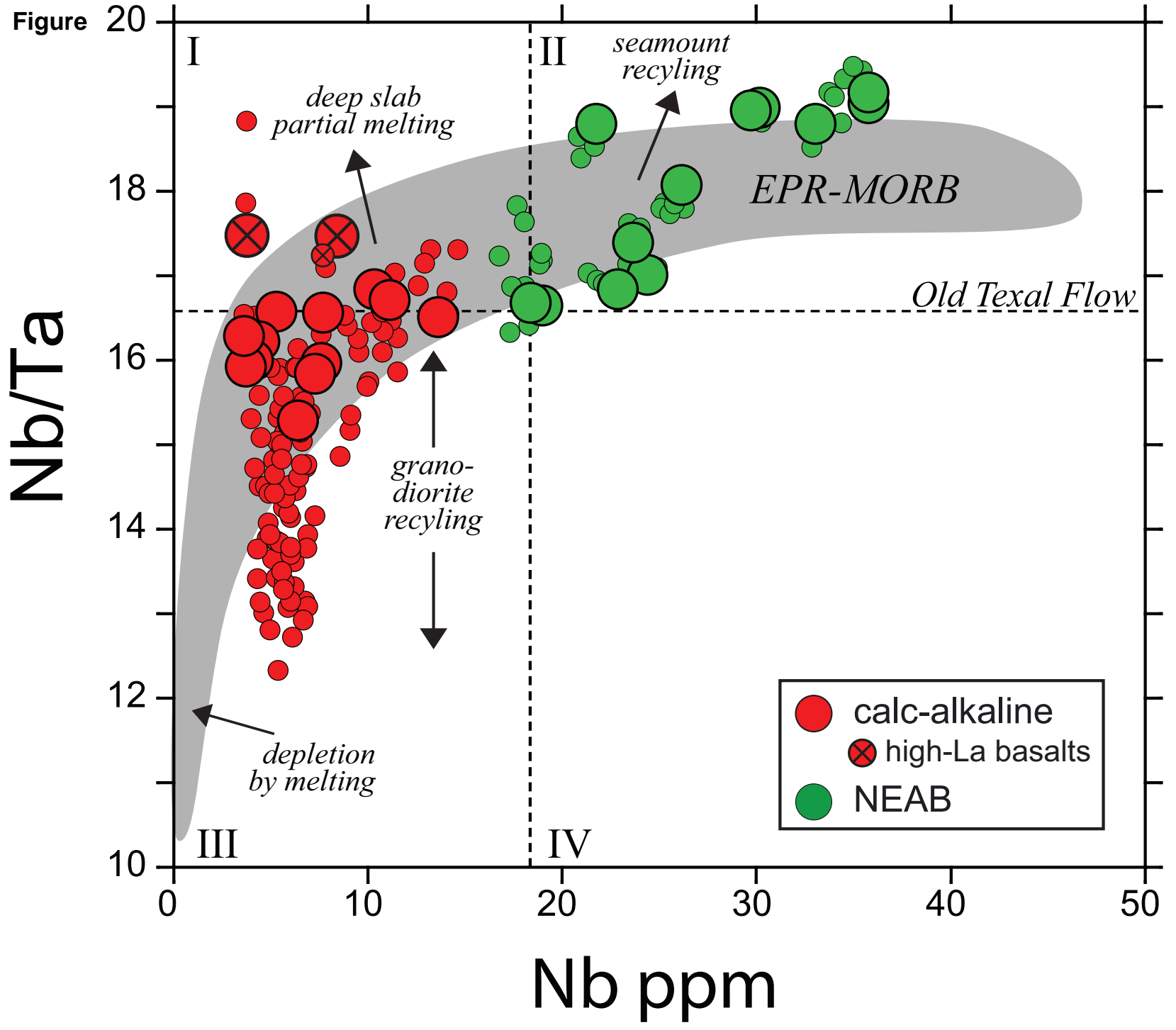

Fig. 16 Straub et al. 